\title{
Modelling of the anthropogenic tritium transient and its decay product helium-3 in the Mediterranean Sea using a high-resolution regional model
}

\author{
M. Ayache ${ }^{1}$, J.-C. Dutay ${ }^{1}$, P. Jean-Baptiste ${ }^{1}$, K. Beranger ${ }^{2}$, T. Arsouze ${ }^{2}$, J. Beuvier ${ }^{3,4}$, J. Palmieri ${ }^{1}$, B. Le-vu ${ }^{1}$, and \\ W. Roether ${ }^{5}$ \\ ${ }^{1}$ Laboratoire des Sciences du Climat et de l'Environnement (LSCE), IPSL, CEA/UVSQ/CNRS, \\ Orme des Merisiers, Gif-Sur-Yvette, France \\ ${ }^{2}$ ENSTA ParisTech, Palaiseau, France \\ ${ }^{3}$ Mercator-Océan, Ramonville Saint-Agne, France \\ ${ }^{4}$ CNRM-GAME (Météo-France, CNRS), Toulouse, France \\ ${ }^{5}$ Institut fur Umweltphysik, University of Bremen, Bremen, Germany \\ Correspondence to: M. Ayache (mohamed.ayache@lsce.ipsl.fr)
}

Received: 23 October 2014 - Published in Ocean Sci. Discuss.: 5 December 2014

Revised: 1 April 2015 - Accepted: 2 April 2015 - Published: 12 May 2015

\begin{abstract}
This numerical study provides the first simulation of the anthropogenic tritium invasion and its decay product helium-3 $\left({ }^{3} \mathrm{He}\right)$ in the Mediterranean Sea. The simulation covers the entire tritium $\left({ }^{3} \mathrm{H}\right)$ transient generated by the atmospheric nuclear weapons tests performed in the 1950s and early 1960s and is run till 2011. Tritium, helium-3 and their derived age estimates are particularly suitable for studying intermediate and deep-water ventilation and spreading of water masses at intermediate/deep levels. The simulation is made using a high-resolution regional model NEMO $(\mathrm{Nu}-$ cleus for European Modelling of the Ocean), in a regional configuration for the Mediterranean Sea called MED12, forced at the surface with prescribed tritium evolution derived from observations.

The simulation is compared to measurements of tritium and helium-3 performed along large-scale transects in the Mediterranean Sea during the last few decades on cruises of R/V Meteor: M5/6, M31/1, M44/4, M51/2, M84/3, and R/V Poseidon: 234. The results show that the input function used for the tritium generates a realistic distribution of the main hydrographic features of the Mediterranean Sea circulation. In the eastern basin, the results highlight the weak formation of Adriatic Deep Water in the model, which explains its weak contribution to the Eastern Mediterranean Deep Water (EMDW) in the Ionian sub-basin. It produces a realistic rep-
\end{abstract}

resentation of the Eastern Mediterranean Transient (EMT) signal, simulating a deep-water formation in the Aegean subbasin at the beginning of 1993, with a realistic timing of deep-water renewal in the eastern basin.

\section{Introduction}

Several recent studies show that the Mediterranean Sea will be particularly sensitive to climate change impacts (Giorgi, 2006; Diffenbaugh and Giorgi, 2012). This basin is surrounded to the north by highly industrialized countries and to the south by countries with high population growth; these factors amplify the existing environmental and water resource problems, and intensify anthropogenic pressure on the basin (Attané, I. and Courbage, 2004; MerMex-Groue, 2011; Gualdi et al., 2013).

Although relatively small, the Mediterranean Sea (Fig. 1) is of sufficient size for its circulation to be governed by largescale ocean dynamics. It is among the most interesting of our planet's semi-enclosed seas because of the great range of processes and interactions which occur within it (MalanotteRizzoli and Robinson, 1988); most physical processes which characterize the global general ocean circulation occur directly or analogously in the Mediterranean Sea. All major 


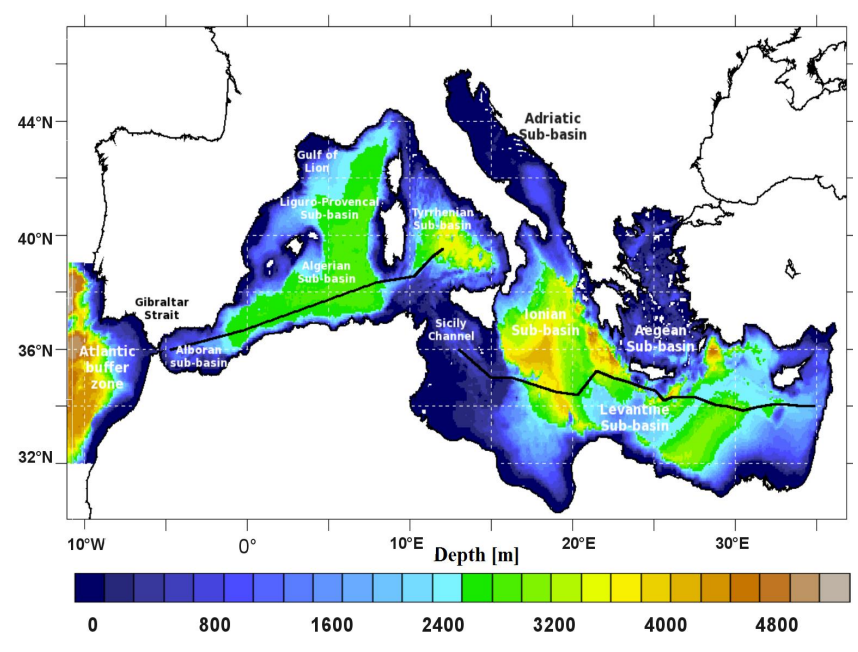

Figure 1. Map of the NEMO-MED12 model domain and bathymetry with location of the main Mediterranean sub-basins. The solid lines represent the trans-Mediterranean sections of the R/V Meteor cruises in 1987, 1995, 1999, 2001 and 2011 for the eastern basin (used in Fig. 7) and of the R/V Poseidon cruises 234, 1997, and Meteor 84/3, 2011, for the western basin (used in Fig. 10).

forcing mechanisms, including air-sea interaction, buoyancy fluxes and lateral mass exchange, are present, as well as intermediate and deep water masses formation (POEM-group, 1992). It thus makes an excellent laboratory test basin for studying processes that affect the global thermohaline circulation.

The circulation of the Mediterranean Sea is usually described in a schematic way as an open thermohaline cell with two closed secondary cells, one for each sub-basin (Lascaratos et al., 1999). In the principal cell, incoming Atlantic Water (AW) is transformed at the surface to the outflowing Levantine Intermediate Water (LIW), which is the main contributor of the Mediterranean Outflow Water (MOW) into the Atlantic. The two secondary cells describe the development of Western Mediterranean Deep Water (WMDW) and Eastern Mediterranean Deep Water (EMDW) (Lascaratos et al., 1999). Deep-water source areas are classically the Adriatic sub-basin for the eastern Mediterranean Basin (EMed) and the Gulf of Lions (Liguro-Provencal sub-basin) for the western Mediterranean Basin (WMed) (Millot and TaupierLetage, 2005). The main product of intermediate waters is the LIW formed in the eastern Levantine sub-basin, at between 200 and $500 \mathrm{~m}$ depth and spreading out across the entire Mediterranean Basin. The Aegean sub-basin is also considered as a source of deep (Cretan Deep Water, CDW) and intermediate waters (Cretan Intermediate Water, CIW) for the EMed. The CIW was found in the layer below the LIW between about 500 and $1200 \mathrm{~m}$ depth (Theocharis et al., 2002; Schlitzer et al., 1991). The out-flowing CDW is no longer dense enough to reach the bottom of the adjacent basins, but ventilates from layers between 1500 and $2500 \mathrm{~m}$
(Theocharis et al., 2002). All abbreviations and acronyms used in the paper are given in Table A1 (CIESM, 2001).

Millot (2013) suggests that the correct name for the intermediate waters outflowing from the eastern basin should not be LIW, but should be the Eastern Intermediate Water (EIW) considered as an evolution of the CIW and LIW signature (and the tEMDW, after the Eastern Mediterranean Transient, EMT, event) combined together rather than an evolution of the LIW alone. The overall formation rate of intermediate and deep Mediterranean Waters (MWs) is estimated to be $90 \%$ of the AW inflow at Gibraltar (10\% being evaporated), of which three-fourths and one-fourth are formed in the eastern and western basins, respectively. These values lead to an average residence time of 50-100 years (Millot and TaupierLetage, 2005).

The circulation of the various waters from/to Gibraltar to/from the zones of deep convective sinking is reasonably well understood, although finer-scale structures are still debated. The formation of the deep waters is also characterized by a decadal variability (e.g. Schroeder et al., 2012; Pinardi et al., 2013). The two most recent examples being the EMT (Roether et al., 2007) and the Western Mediterranean Transient (WMT) (Schroeder et al., 2008).

The EMT was the major climatic event in the circulation and water mass properties of the Mediterranean in the last century. The Adriatic has been historically considered as the main contributor to the deep and bottom waters of the Ionian and Levantine basins. However, the Aegean has also been reported as a possible secondary source of dense waters, lower intermediate and/or deep (Nielsen, 1992; Miller, 1963; Schlitzer et al., 1991), that affected mainly the area adjacent to the Cretan Arc in the eastern Mediterranean. From 1988 onwards, the most important changes ever detected in the thermohaline circulation and water properties started basinwide. A shift in the formation site of the deep and bottom waters from the Adriatic to the Aegean Sea occurred (Roether et al., 1996, 2007; Malanotte-Rizzoli et al., 1999; Lascaratos et al., 1999; Theocharis et al., 1992, 1999). The Agean Sea has produced large quantities of a very dense water mass, namely the CDW that next overflowed through the Cretan Arc Straits, producing denser water than the previously existing deep and bottom water masses (EMDW).

Different hypotheses concerning the preconditioning of the EMT and its timing have been proposed in the literature, mainly based on the available observations, such as (i) changes in circulation patterns leading to blocking situations concerning the Modified Atlantic Water (MAW) and the LIW (Samuel et al., 1999; Theocharis and Kontoyiannis, 1999; Malanotte-Rizzoli et al., 1999); (ii) changes in the local atmospheric forcing over the Aegean combined with long-term salinity change (Theocharis et al., 1999; Lascaratos et al., 1999); (iii) a decrease in the Black Sea freshwater input due to a reduction of the river runoff which flow into it (Zervakis et al., 2000; Stanev and Peneva, 2002); (iv) internal redistribution of salt (Klein et al., 1999); (v) the start of the intense 
winter convection in 1987 in the northern Aegean Sea (Zervakis et al., 2000; Gertman et al., 2006); and (vi) the occurrence of two successive winters (1991-1992 and 1992-1993) with strong and deep convection in all the Aegean Sea; these convection events are triggered by strong surface heat losses during these winters (Josey, 2003). All these preconditioning factors (or at least some of them) could have changed the Aegean Sea stratification, leading to a less stable water column that was then easily mixed during the very cold 1992 and 1993 winters.

The WMT started during the mid-2000s (winter 2005) in the Gulf of Lions, during which a huge volume of Western Mediterranean Deep Water (WMDW) was formed with unusually high temperature and salinity. Winter 2005 was one of the coldest and driest winters in the last 40 years; the strong surface cooling and evaporation with highly favourable preconditioning triggered deep convection. López-Jurado et al. (2005) suggested that the unusual characteristics of the 2005 convection event could be due to a change in the characteristics of the water masses advected until forming the zone of WMDWs after EMT. Herrmann et al. (2010) rather suggest that the higher temperature and salinity of the new WMDW formed in 2005 are due to the absence of an intense convective winter in the 1990s and early 2000s in the NWMed, leading to an accumulation of heat and salt in the intermediate and deep layers of this area.

These two events (EMT and WMT) give a good illustration of the impact of decadal variability in the Mediterranean Sea and have been observed and confirmed by observation. However, as the observations are discrete in time and space, they have not led to quantification and a complete understanding of these events.

The large-scale circulation patterns and the deep-water ventilation are difficult to measure directly. Various concepts of our present knowledge of ocean ventilation were originally deduced from the distributions of hydrographic tracers such as salinity, oxygen and nutrients (Broecker and Peng, 1982; Sarmiento and Gruber, 2006). Hydrographic tracers, however, tell us little about the time rates of the processes that are involved in ocean ventilation (Doney et al., 1992). With the development of in situ measurement techniques, oceanographers have increasingly turned to transient tracer species, in particular radiocarbon, tritium and the chlorofluorocarbons (Broecker and Peng, 1982; Sarmiento and Gruber, 2006). These geochemical transient tracers provide additional information that allows us to constrain timescales of ocean ventilation. In this paper, we use tritium $\left({ }^{3} \mathrm{H}\right)$ and its decay product helium-3 $\left({ }^{3} \mathrm{He}\right)$ to evaluate the circulation simulated by a high-resolution model of the Mediterranean Sea.

An ocean general circulation model is an excellent tool for investigating the mechanisms that control the present ocean circulation, such as the inter-basin exchange of the thermohaline circulation (Béranger et al., 2004; Gasparini et al., 2005), and allows us to assess different hypotheses proposed to explain exceptional events. It also provides an opportunity for investigating the future evolution of the Mediterranean Sea circulation and its effect on the climate of that region (Drobinski et al., 2012; Beuvier et al., 2010; Herrmann et al., 2010; Somot et al., 2006). However, these increasingly used models should be validated to test their realism against in situ observations. Passive tracers such as anthropogenic tritium and helium-3 are particularly suitable for evaluating the large-scale dynamics simulated by these models on decadal timescales. The potential of using tritium and ${ }^{3} \mathrm{He}$ data jointly is based on the fact that these two tracers form a radioactive mother-daughter pair, which allows one to deduce tracer-age estimations. The ${ }^{3} \mathrm{H}-{ }^{3} \mathrm{He}$ age provides constraints on sub-surface water transport and mixing for processes with timescales of the order of decades such as thermocline ventilation or deep water formation and propagation.

The present study provides the first simulation of the ${ }^{3} \mathrm{H}-$ ${ }^{3} \mathrm{He}$ distribution, and its age-related tracer distribution, using a high-resolution regional model of the entire Mediterranean Sea. The simulations run between 1950 and 2011, which cover the period of nuclear bomb tests in the atmosphere in the late 1950 s and early 1960 s. Simulated ${ }^{3} \mathrm{H}-{ }^{3} \mathrm{He}$ concentrations in the water column are compared with observations from R/V Meteor cruises: M5/6-1987, M31/1-1995, M44/4-1999, M51/2-2001, M84/3-2011, and Poseidon 2321997. These data allow us to critically examine the dynamics of the NEMO-MED12 ocean model (Nucleus for European Modelling of the Ocean, in a regional configuration for the Mediterranean Sea called MED12) (Lebeaupin Brossier et al., 2011; Beuvier et al., 2012a; Palmiéri et al., 2015) and to evaluate the ability of this model to reproduce the main features of the circulation and mixing of the Mediterranean Sea water masses and their interannual variability, including the exceptional events observed in the ventilation of the deep waters.

\section{Presentation of tracers}

Tritium was almost the first transient tracer to be used extensively in oceanography (e.g. Östlund, 1969; Clarke et al., 1976). It is a powerful tracer for studying thermocline ventilation just like chlorofluorocarbons (Sarmiento and Gruber, 2006). Tritium is the only radioactive isotope of hydrogen that decays by beta emission to ${ }^{3} \mathrm{He}$ (which is the stable isotope of helium) with a half-life of 12.32 years (Lucas and Unterweger, 2000). It is produced in the upper atmosphere by cosmic ray spallation and fast neutron interactions with ${ }^{14} \mathrm{~N}$ to form one ${ }^{3} \mathrm{H}$ atom and ${ }^{12} \mathrm{C}$; after oxidation to tritiated water it takes part in the hydrological cycle. The anthropogenic tritium (mainly from atmospheric nuclear weapons tests) was added to the atmosphere in significant amounts in the 1950s and early 1960s. This completely masked the natural background of tritium (Weiss et al., 1979). The input 
of tritiated water from the atmosphere to the ocean involves several factors, such as precipitation, evaporation and runoff (Weiss et al., 1979). The tritium signal that entered the surface of the ocean provides an interesting tracer of ocean circulation on timescales from a few years up to a few decades (Jenkins, 1987). Tritium is reported in conventional Tritium Units (TU), in which $1 \mathrm{TU}$ is a tritium to hydrogen $\left({ }^{3} \mathrm{H} / \mathrm{H}\right)$ ratio of $10^{-18}$. This unit is named TU81 when concentrations are decay corrected to a common date of 1 January 1981 (Mann et al., 1982).

The tritium ratio in the Mediterranean surface waters rose to $25-30 \mathrm{TU}$ in 1964 at the peak time of atmospheric nuclear weapons tests, a factor of about 100 above the natural level (Fig. 2), and thereafter declined 30-fold up to 2011 (Roether et al., 2013). This decline was due to a combination of cessation of new bomb tritium from the atmosphere and its radioactive decay (half-life of 12.32), which produced significant quantities of helium-3 and mixed with the deeper water masses (Roether et al., 2013). Limitations in the use of tritium alone, as a water mass tracer, arise from its radioactive nature and from dispersion of the bomb signal in the ocean, leading to difficulties in interpreting the tritium distribution. These limitations can be partially overcome by using tritium in combination with its decay product helium3. This isotope is a useful tracer for investigating the deep ocean circulation and for evaluating ocean general circulation models, because it is a stable and conservative nuclide that does not take part in any chemical or biological processes. Helium-3 is a rare isotope of helium, found essentially in solubility equilibrium with its atmospheric concentration at the surface, with a slightly lower ${ }^{3} \mathrm{He} /{ }^{4} \mathrm{He}$ ratio in sea water than in the atmosphere $\left(\delta^{3} \mathrm{He}_{\mathrm{sw}}=-1.8 \%\right.$, where $\left({ }^{3} \mathrm{He}_{\mathrm{sw}}(\%)=100\left(R_{\mathrm{sw}} / R_{\text {air }}-1\right)\right.$, where $R={ }^{3} \mathrm{He} /{ }^{4} \mathrm{He}$ and $R_{\text {air }}=1.384 \times 10^{-6}$ ) (Clarke et al., 1976; Farley et al., 1995). Helium-3 in the ocean originates from three different sources: (i) gas dissolution in equilibrium with atmospheric helium; (ii) addition by radioactive decay of tritium (called tritiugenic helium-3); and (iii) by injection of helium-3 into the oceans by the hydrothermal activity at deep sea spreading ridges, and also from the sediment above crusts by $\alpha$ decay of heavy elements (called terrigenic helium-3). The most commonly used method of isolating the tritiugenic portion of helium-3 is the two-step procedure of Roether et al. (1998) and Roether and Well (2001), using concurrent values of $\mathrm{He}, \delta^{3} \mathrm{He}$ and neon $(\mathrm{Ne})$ concentration, because the $\mathrm{Ne}$ generates a similar excess as the ${ }^{3} \mathrm{He}$, but has no sources in the ocean interior. This methodology has already been applied on tritium data by Roether et al. (1998, 2013).

Transient tracers such as tritium ${ }^{3} \mathrm{H},{ }^{3} \mathrm{He}$ and chlorofluorocarbon (CFC) can potentially give us valuable information on the timescales on which the ocean is ventilated. Jenkins and Clarke (1976) combined measurements of ${ }^{3} \mathrm{H}$ and ${ }^{3} \mathrm{He}$ to estimate the elapsed time since the water parcel has been isolated from exchange with the atmosphere, when the ${ }^{3} \mathrm{H}-{ }^{3} \mathrm{He}$ clock is set to zero (called the ${ }^{3} \mathrm{H}-{ }^{3} \mathrm{He}$ age). This method has

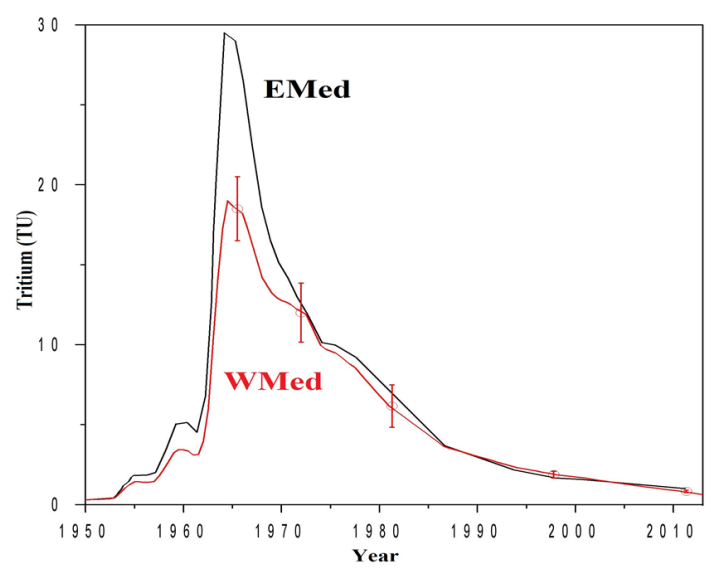

Figure 2. History of tritium concentrations in Mediterranean surface waters. The curve for the eastern basin (in black) is taken from Roether et al. (2013). For the western basin (in red), the curve is homothetic of that of the eastern basin, with ratios constrained by available tritium surface data: ODYSSEUS-1965 (Ostlund, 1969); PHYCEMED-1981 (Andrié and Merlivat, 1988); ORIGNY-1972, POSEIDON 232-1997 and METEOR 84-2011 (Roether et al., 2013); DEWEX-2013 (S. Charmasson, personal communication, 2013).

been employed in various fields in addition to oceanography (Jenkins, 1982, 1987).

The ${ }^{3} \mathrm{H}-{ }^{3} \mathrm{He}$ age is set for an isolated parcel of water that does not contain an excess of helium-3 at the initial time at the surface. It is defined as

$$
\begin{aligned}
& { }^{3} \mathrm{H}_{(t)}={ }^{3} \mathrm{H}_{0} \cdot \mathrm{e}^{-\lambda t}, \\
& { }^{3} \mathrm{He}_{(t)}={ }^{3} \mathrm{H}_{0}\left(1-\mathrm{e}^{-\lambda t}\right), \\
& \left.\tau=\lambda^{-1} \cdot \ln \left(\left(\left[{ }^{3} \mathrm{H}\right]+\left[{ }^{3} \mathrm{He}\right]\right) /\left[{ }^{3} \mathrm{H}\right]\right)\right),
\end{aligned}
$$

where $\tau$ in years is the ${ }^{3} \mathrm{H}-{ }^{3} \mathrm{He}$ age, ${ }^{3} \mathrm{H}_{0}$ is the initial concentration of ${ }^{3} \mathrm{He}, \lambda$ is the decay constant $=\left(\ln (2) / T_{1 / 2}\right)$ when $T_{1 / 2}$ is the half-life for ${ }^{3} \mathrm{H}$.

This age, $\tau$, combines the information implicit in the two tracers, while at the same time largely eliminating the dependence on initial conditions, and gives us an estimate of renewal rates and residence times in years; however, the ${ }^{3} \mathrm{H}-$ ${ }^{3} \mathrm{He}$ age is not conservative with respect to mixing and are typically biased towards younger values (Jenkins and Clarke, 1976). Timescales or rates deduced from tracers do not represent an intrinsic property of the flow; they indeed reflect the age of the tracer not of the water (Haine and Hall, 2002; Delhez et al., 2003). Mixing tends to reduce the value of the tracer age compared to the true ventilation age (e.g. Thiele and Sarmiento, 1990). This was quantified by (Jenkins, 1987) in terms of an advection-diffusion relationship for the ${ }^{3} \mathrm{H}-$ ${ }^{3} \mathrm{He}$ age. He showed that for areas away from the turbulent boundary regions, such as subtropical gyre, the ${ }^{3} \mathrm{H}-{ }^{3} \mathrm{He}$ age is accurate to within $10 \%$ for timescales less than a decade, and for timescales of a few decades, the bias is of the order 
of $20-30 \%$. Moreover, in frontal regions and where mixing is more important, the interpretation is more complex. Even though Eq. (3) is non-linear, its use offers many advantages in analyzing tracer data, because the boundary condition for the age is well known at the surface, which reduces the uncertainty associated with the tracer input function.

\section{Method}

\subsection{Description of the model}

The model used in this work is a free surface ocean general circulation model NEMO (Madec and NEMO-Team., 2008) in a regional configuration called NEMO-MED12 (Beuvier et al., 2012a). NEMO-MED12 covers the whole Mediterranean Sea and also extends into the Atlantic Ocean to $11^{\circ} \mathrm{W}$ (buffer zone). The horizontal resolution of the NEMO-MED12 grid is $1 / 12^{\circ}$ thus varying between 6.5 and $8 \mathrm{~km}$ from 46 to $30^{\circ} \mathrm{N}$ in latitude, and between 5.5 and $7.5 \mathrm{~km}$ in longitude. This scale permits representation of mesoscale features (see a comparison with the first Rossby deformation radius in the Mediterranean Sea in Beuvier et al. (2012a). The vertical resolution (50 levels) ranges from $1 \mathrm{~m}$ in the upper layer, to $450 \mathrm{~m}$ at bottom. We use partial steps to adjust the last numerical level with the bathymetry. NEMO-MED12 is the result of a suite of Mediterranean regional versions of OPA and NEMO: OPAMED16 (Béranger et al., 2005), OPA-MED8 (Somot et al., 2006), NEMOMED8 (Beuvier et al., 2010), NEMO-MED12 has been used to study the anthropogenic carbon uptake (Palmiéri et al., 2015), the mixed layer response under high-resolution airsea forcings (Lebeaupin Brossier et al., 2011), the WMDW formation (Beuvier et al., 2012a) and the transport through the Strait of Gibraltar (Soto-Navarro et al., 2014). Full details of the model and its parameterizations are given by Beuvier et al. (2012a) and Palmiéri et al. (2015).

The initial conditions (temperature, salinity) for the Mediterranean Sea come from the MedAtlas-II (MEDARMedAtlas-group, 2002; Rixen et al., 2005) climatology weighted by a low-pass filter with a time window of 10 years using the MedAtlas data covering the 1955-1965 period following Beuvier et al. (2012a). The simulation then starts with the initial conditions of an ocean at rest, close to the state of the Mediterranean Sea in October 1958. For the Atlantic buffer zone, the initial state comes from the 2005 World Ocean Atlas for temperature (Locarnini et al., 2006), and salinity (Antonov et al., 2006). River runoff is taken from the interannual data set of Ludwig et al. (2009) and Vörösmarty et al. (1996). The Black Sea is not explicitly represented in the NEMOMED12 model. Instead, in the model the water exchange between the Black Sea and the Mediterranean Sea is treated, as a river (surface freshwater input) located at the Dardanelles strait, with a flux corresponding to Dardanelles' net budget estimates of (Stanev and Peneva, 2002).

This simulation was forced by the atmospheric fluxes from the high-resolution $(50 \mathrm{~km})$ ARPERA data set (Herrmann and Somot, 2008; Herrmann et al., 2010). NEMO-MED12 is forced by ARPERA daily fields of the momentum, evaporation and heat fluxes over the period 1958-2013. For the surface temperature condition, a relaxation term toward ERA40 sea surface temperature (SST) is applied for the heat flux (Beuvier et al., 2012a). This term plays the role of a firstorder coupling between the SST of the ocean model and the atmospheric heat flux (Barnier et al., 1995), ensuring the consistency between those two terms. The value of the relaxation coefficient is spatially constant and taken equal to $-40 \mathrm{~W} \mathrm{~m}^{-2} \mathrm{~K}^{-1}$, following the CLIPPER Project Team (1999). It is equivalent to a 1.2-day restoring timescales for a surface layer of $1 \mathrm{~m}$ thickness (Beuvier et al., 2012a).

The exchanges with the Atlantic Ocean are performed through a buffer zone between $11^{\circ} \mathrm{W}$ and the Strait of Gibraltar, where 3-D temperature and salinity model fields are relaxed to the observed climatology (Beuvier et al., 2012a). To conserve the Mediterranean Sea water volume, the total sea surface height (SSH) is restored in the Atlantic buffer zone from the GLORYS1 reanalysis (Ferry et al., 2010). A 1.5 turbulent closure scheme (Turbulent Kinetic Energy, TKE) is used for the vertical eddy diffusivity (Blanne and Delecluse, 1993) with an enhancement of the vertical diffusivity coefficient (Beuvier et al., 2012a).

The atmospheric forcing used by Beuvier et al. (2012a) includes some modifications to improve dense water fluxes through the Cretan Arc during the EMT (Beuvier et al., 2010) showed that the previous version of NEMO-MED at $1 / 8^{\circ}$ resolution (NEMO-MED8) was able to reproduce a transient in deep-water formation as observed for the EMT, but the simulated transient produced less EMDW. Beuvier et al. (2012b) later performed a simulation with NEMOMED12 with comparable forcing between October 1958 and December 2012. To improve the characteristics of the simulated EMT, namely the density of newly formed EMDW during 1992-1993, its weak formation rate, as well as its shallow spreading at $1200 \mathrm{~m}$, made a sensitivity test with modified forcing. The ARPERA forcings were modified over the Aegean sub-basin, by increasing mean values as done by (Herrmann et al., 2008) to study the Gulf of Lions. More specifically, during November to March in the winters of 1991-1992 and 1992-1993, they increased daily surface heat loss by $40 \mathrm{~W} \mathrm{~m}^{2}$, daily water loss by $1.5 \mathrm{~mm} \mathrm{~d}^{-1}$, and the daily wind stress modulus by $0.02 \mathrm{~N} \mathrm{~m}^{-2}$. That resulted in average winter time increases in heat loss $(+18 \%)$, water loss $(+41 \%)$ and wind intensity $(+17 \%)$ over the Aegean sub-basin. The increased heat and water losses allow NEMOMED12 to form denser water masses in the Aegean Sea during the most intense winters of the EMT, while increased wind stress drives more intense mixing via winter convection; it produces enhanced convection that accelerates the 
transfer of surface temperature and salinity perturbations into intermediate and deep layers of the Aegean Sea.

${ }^{3} \mathrm{H}-{ }^{3} \mathrm{He}$ are passive tracers which do not affect the ocean circulation (as opposed to active tracers such as temperature and salinity). They can be run in an off line mode. It means that circulation fields (velocity, temperature, salinity) are calculated first with a dynamical model and later used to simulate the transport of passive tracers such as tritium. Offline simulations are done for computational efficiency. They allow us to run simulation of different passive tracers in pre-computed transport fields instead of re-computing them, which is very costly. The same approach was used by (Palmiéri et al., 2015) for simulating CFC and anthropogenic $\mathrm{CO}_{2}$ in the Mediterranean Sea. This choice is justified by the fact that these tracers are passive. Their injection does not alter the dynamics of the ocean, and they have no influence on the physical properties of water, unlike hydrographic tracers such as temperature or salinity. The ${ }^{3} \mathrm{H}-{ }^{3} \mathrm{He}$ simulation used a circulation from NEMO-MED12 dynamical model (Beuvier et al., 2012a). The transports of passive racers are driven by NEMO-MED12 physical fields using an advection-diffusion equation, plus the sources minus the sinks (4). Physical forcing fields are read daily and interpolated each time step of $20 \mathrm{~min}$. The rate of change of each specific passive tracer $C$ is:

$\frac{\delta C}{\delta t}=S(C)-U \cdot \nabla C+\nabla \cdot(K \nabla C)$,

where $S(C)$ is the source to sink of the tracer; in our case this term represents the radioactive decay of tritium to helium3. $U \cdot \nabla C$ is advection of the tracer in the three directions. $\nabla$. $(K \nabla C)$ is lateral and vertical diffusion, with the same parameterization as for the hydrographic tracers. For the turbulent diffusion (horizontally and vertically), we use the same parameterization than Beuvier et al. (2012a).

The dynamical model was forced with the ARPERA forcing during the 1958-2013 period. The first 7 years (19581964) are considered as a spin-up and are not used in the offline simulations of passive tracers. Rather, the next 10 years (ARPERA forcing during 1965-1974) are continuously repeated until 1975 to drive our offline simulations of both passive tracers from 1951 (beginning of the simulation) until 1975. That forcing period was selected because it does not include intense events like the EMT or the WMT (Schroeder et al., 2008); we thus considered this period as best suited to produce reasonable circulation fields for the Mediterranean Sea (Beuvier et al., 2010, 2012b; Beuvier, 2011). Then to complete the offline ${ }^{3} \mathrm{H}-{ }^{3} \mathrm{He}$ simulations, we applied the NEMO-MED12 circulation fields corresponding to the remaining 1975-2011 period forcing.

\subsection{Tracer boundary conditions}

The usefulness of anthropocentric ${ }^{3} \mathrm{H}$ as a tracer of oceanic processes is strongly limited by our knowledge of the tritium boundary condition at the air-sea interface. Generally, there are two methods of determining the boundary conditions for oceanic tritium simulations. The first method consists of prescribing the temporal evolution of the tritium concentration over the entire surface of the ocean from the available observations (Jia and Richards, 1996). This method can be applied only in those basins where the observations are sufficient to accurately constrain the tritium concentration in surface water (such as the North Atlantic and the Mediterranean Sea). The second method is to calculate the net flux of tritium from the atmosphere to the ocean, as a function of the hydrological variables (precipitation, evaporation, relative humidity and river runoff), available in climatological databases (Sarmiento, 1983).

Levels of tritium in precipitation are relatively well documented, the data are held centrally by the Global Network of Isotopes in Precipitation (GNIP) of the International Atomic Energy Agency and the World Meteorological Organization (Doney et al., 1992). Mathematical formulations have been developed from the GNIP measurement network to represent the spatio-temporal variations of tritium concentrations with rainfall, such as the formulation of Weiss and Roether (1980) and Doney et al. (1992). The tritium levels in water vapour are much less well documented compared to those in precipitation, which has prevented appropriate formulations from being developed. Determinations of tritium content in water vapour are generally based on the content of tritiated water $\left({ }^{3} \mathrm{H}_{2} \mathrm{O}\right)$ in precipitation. Weiss and Roether (1980) assumed tritium equilibrium (ratio about 0.85 ) between precipitation and marine water vapour. This approach represents a significant source of uncertainty in the input function, and it is difficult to verify this hypothesis because of the transient nature of the tritium in the water vapour. The levels of tritium in rivers are also very poorly documented. However, except for the Adriatic sub-basin, rivers make a small contribution to the Mediterranean Sea (Weiss and Roether, 1980). The levels of tritium in Black Sea are also very poorly documented, so that its flux to the Mediterranean Sea cannot be estimated; therefore, we do not prescribe any flux of tracer from the Black Sea in our simulation.

For this study, we used two time series of the tritium concentration in the Mediterranean surface waters (between 1950 and 2011; Fig. 2) developed for the eastern basin by Roether et al. (2013), and for the western basin the curve is homothetic to that of the east, with ratios constrained by available tritium surface data from Odysseus1965 (Östlund, 1969); Phycemed-1981 (Andrie and Merlivat, 1988); Origny-1972, Poseidon 232-1997 and Meteor 842011 (Roether et al., 2013); and Dewex-2013 (S. Charmasson, personal communication, 2013). In the Mediterranean Sea, the tritium concentrations at the surface are relatively high compared to the global ocean, because of the intracontinental situation of the basin. Indeed, levels of tritium on the continent are generally higher compared to those in the oceans because on land, rainwater re-evaporates without 

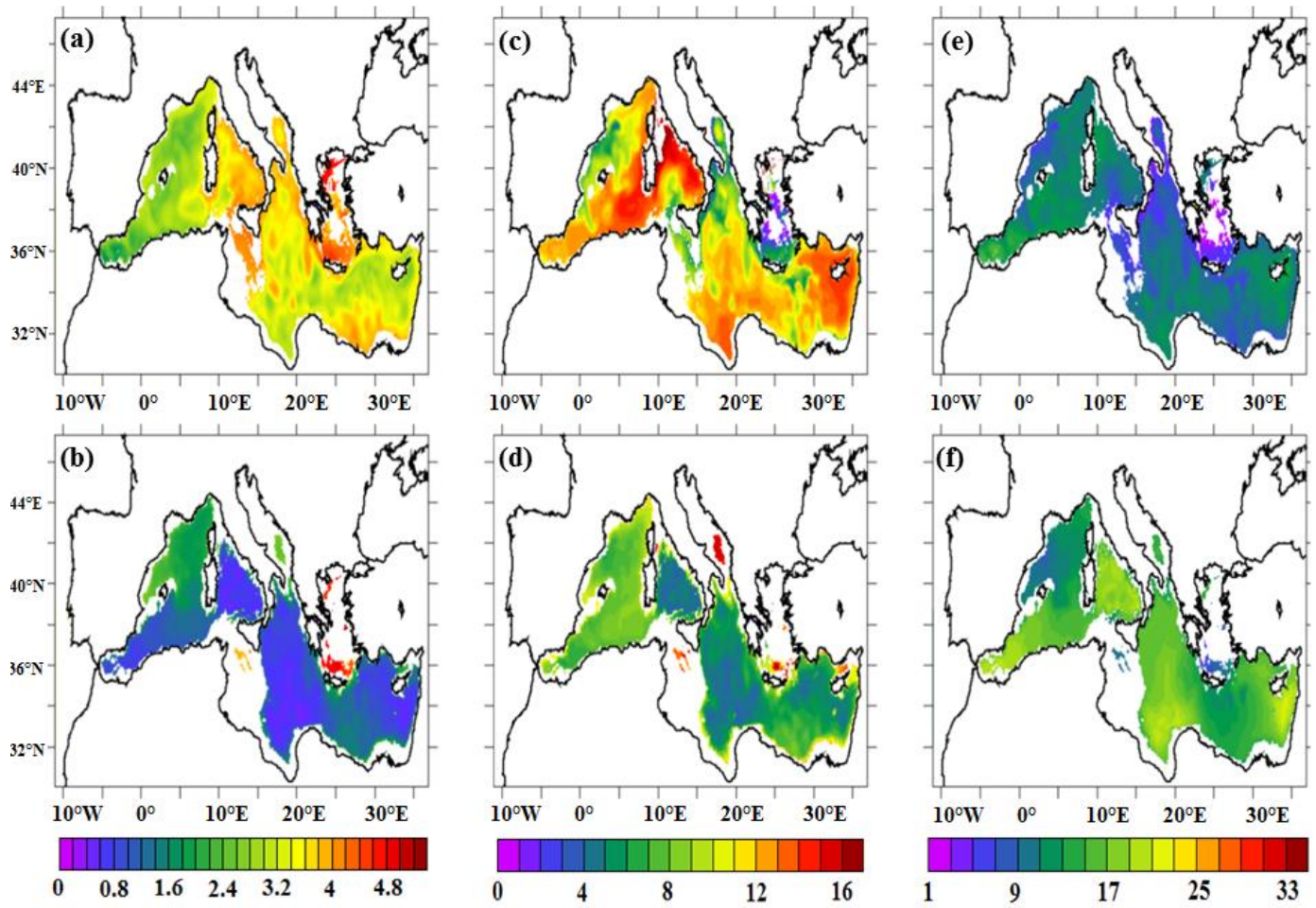

Figure 3. Output of model for March 1987, (a) and (b) concentrations of tritium (in TU) in the LIW layer (average depth between 380 and $540 \mathrm{~m}$ ) and for the deep-water layer between 1000 and $1600 \mathrm{~m}$, (c) and (d) same for helium-3 (in \%), (e) and (f) idem for the ${ }^{3} \mathrm{H}-{ }^{3} \mathrm{He}$ age (in years).

significant dilution. Note that the EMed surface-water tritium concentrations have always exceeded those in the WMed due to reduced influence of the Atlantic, for which the tritium surface water concentrations have generally been lower (Dreisigacker and Roether, 1978).

In our simulations, we therefore used the first method, as we directly prescribe the tritium concentrations for each basin with a transition zone between the two basins created by a linear interpolation of these two time series in the Strait of Sicily. In addition to prescribing the surface tritium concentrations (for each year), we impose a zero concentration of tritiugenic helium-3 (produced only by the radioactive decay of tritium) in the surface layer. Over time, the radioactive decay of tritium produces helium-3, following the law of radioactive decay, which generates the concentration of the tritiugenic helium- 3 in the water column. In this study, we simulate only the tritiugenic helium-3 (anthropogenic source), without representing the terrigenic helium-3 component (natural source). To isolate this tritiugenic helium-3 component in the observations, we apply the procedure of Roether et al. (1998) and Roether and Well (2001).

\section{Results}

\subsection{Basin-wide distributions}

We begin our analysis by providing a descriptive overview of the global horizontal distribution of the two modelled tracers (tritium and helium-3), and of the derived tracer age. We average between depths of 380 and $540 \mathrm{~m}$, as representative of the intermediate waters, including the LIW layer, and between 1000 and $1600 \mathrm{~m}$ depths (below the permanent thermocline) for the deep waters. Figures 3, 4, 5 and 6 present the model results for 1987, 1995, 1999 and 2011, respectively. These horizontal figures show the distributions of tracers, for the intermediate waters in upper panels (a, c and e) and in lower panels (b, $d$ and $f$ ) for deep water. The analysis at these two levels provides a good visualization of the source of ventilation for the interior of the Mediterranean Sea, and the connection between the surface, intermediate and deep water.

The tracer distributions in 1987 (pre-EMT) display a classical situation for the Mediterranean Sea circulation. Relatively high tritium concentrations are simulated in the intermediate waters over the whole EMed, except in the northern Levantine Basin considered as the main source of LIW, and south of France in the Gulf of Lions where the source of WMDWs is located. Consequently, the tritium penetra- 

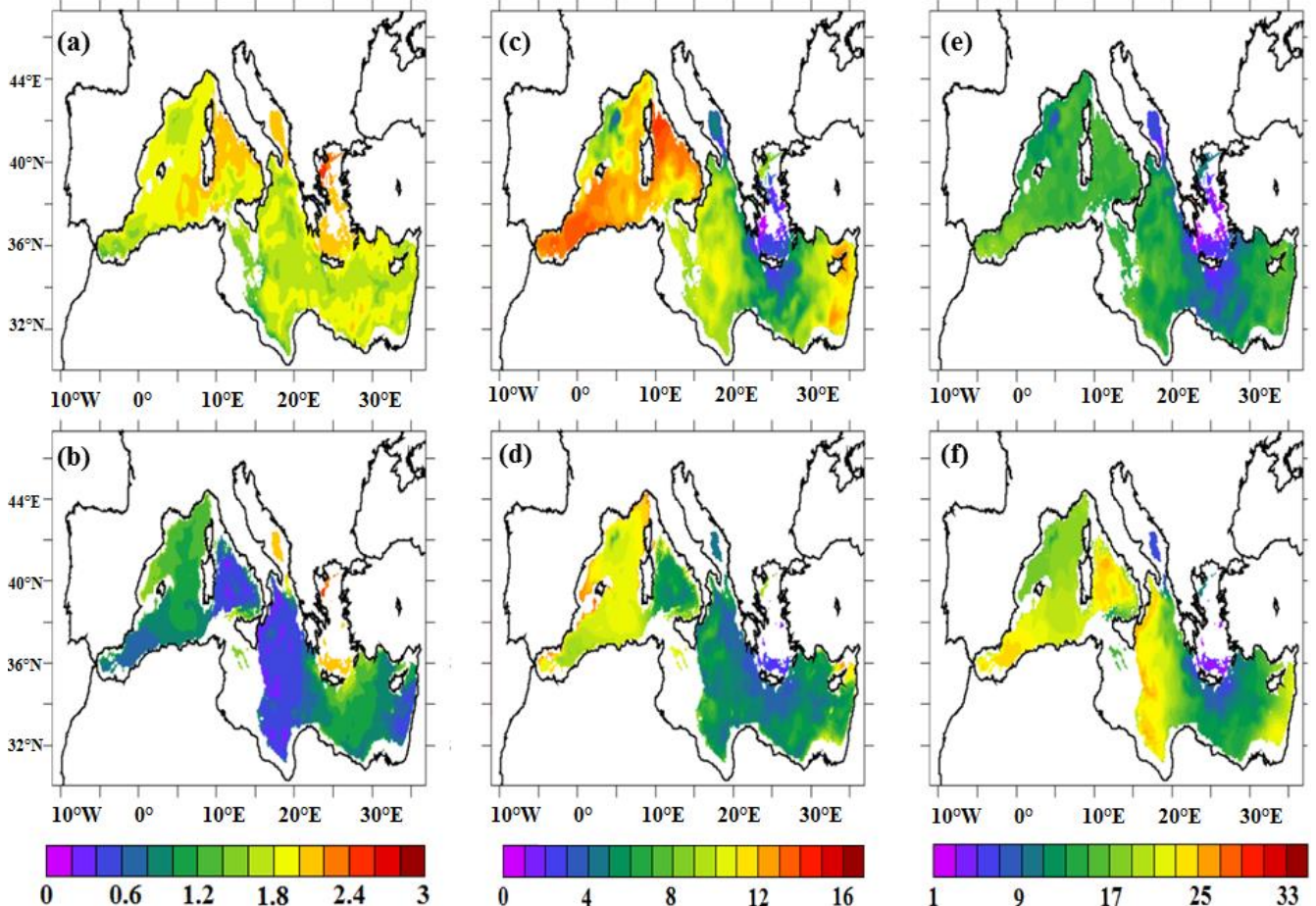

Figure 4. Output of model for March 1995, (a) and (b) concentrations of tritium (in TU) in the LIW layer (average depth between 380 and $540 \mathrm{~m}$ ) and for the deep-water layer between 1000 and $1600 \mathrm{~m},(\mathbf{c})$ and (d) same for helium-3 (in \%), (e) and (f) idem for the ${ }^{3} \mathrm{H}-{ }^{3} \mathrm{He}$ age (in years).
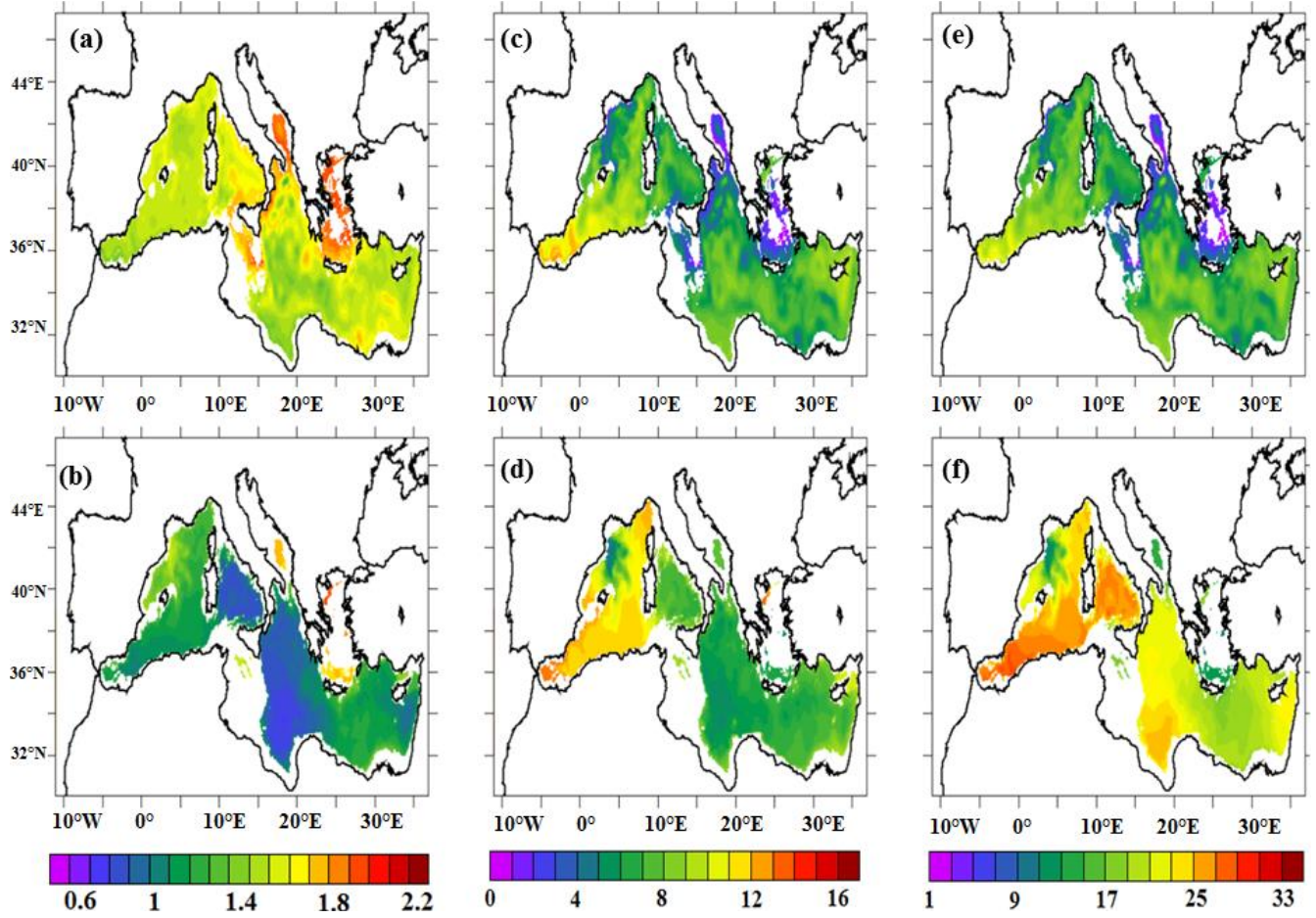

Figure 5. Output of model for March 2005, (a) and (b) concentrations of tritium (in TU) in the LIW layer (average depth between 380 and $540 \mathrm{~m}$ ) and for the deep-water layer between 1000 and $1600 \mathrm{~m}$, (c) and (d) same for helium-3 (in \%), (e) and (f) idem for the ${ }^{3} \mathrm{H}-{ }^{3} \mathrm{He}$ age (in years). 

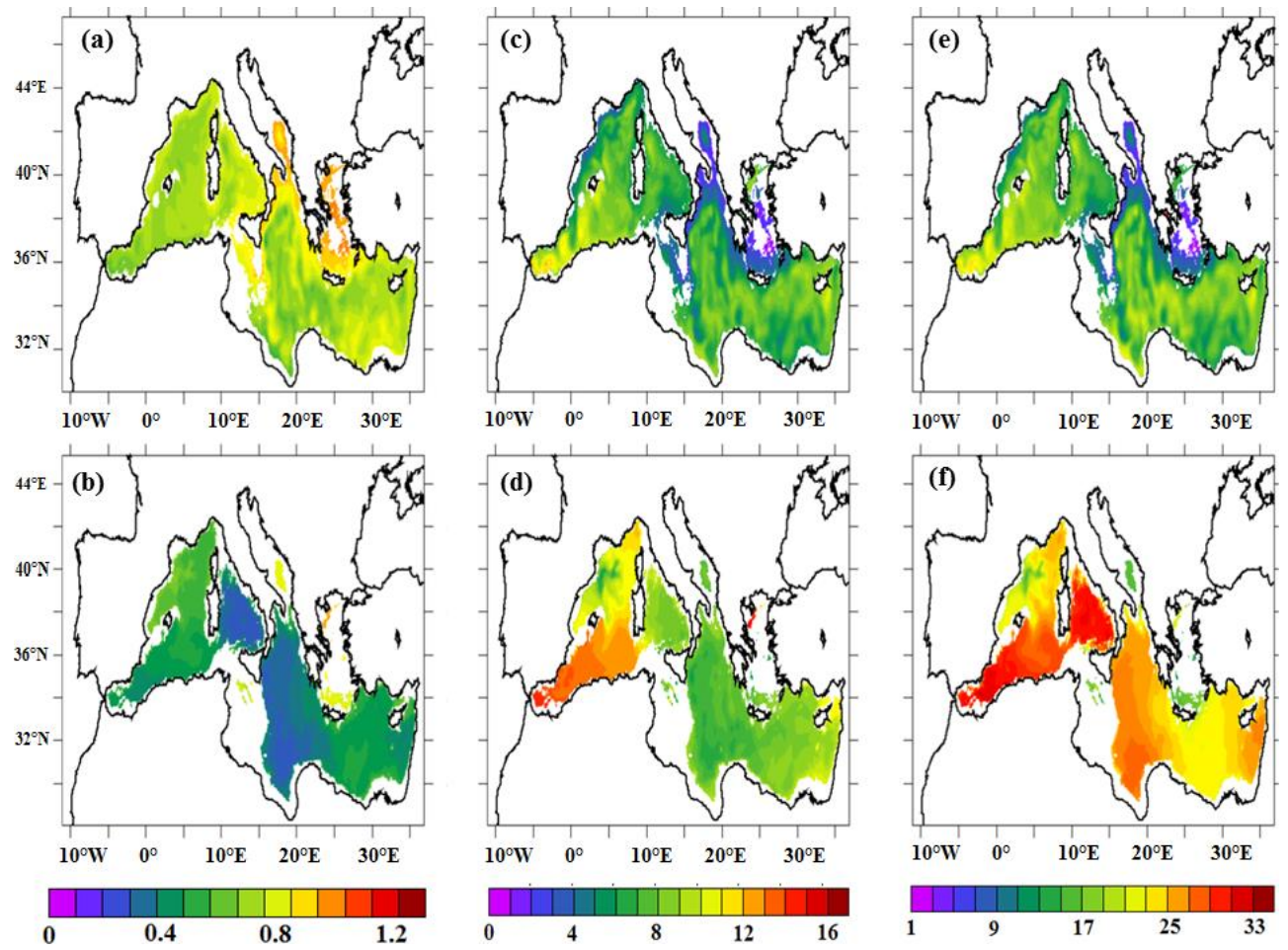

Figure 6. Output of model for March 2011, (a) and (b) concentrations of tritium (in TU) in the LIW layer (average depth between 380 and $540 \mathrm{~m}$ ) and for the deep-water layer between 1000 and $1600 \mathrm{~m}$, (c) and (d) same for helium-3 (in \%), (e) and (f) idem for the ${ }^{3} \mathrm{H}-{ }^{3} \mathrm{He}$ age (in years).

tion is more important in these regions, where higher tritium concentrations are simulated in the deep waters compared to the surrounding waters. The lowest helium-3 concentrations in intermediate waters of EMed are located in the southern Adriatic sub-basin (Fig. 3c) as a result of sub-surface mixing caused by significant intermediate water formation. The tracer-age distribution in 1987 (Fig. 3e and f) highlights the region with recent water mass ventilation. It shows a good consistency between the youngest water, with a tracer age under 7 years, and the area characterized by low levels of ${ }^{3} \mathrm{He}$ and with a high ${ }^{3} \mathrm{H}$ concentration, especially in the Levantine sub-basin, off the south of France, and the Adriatic sub-basin.

In 1995 gradients throughout the Mediterranean become more pronounced for the spatial tritium distribution in both intermediate and deep waters. The contrast is particularly pronounced in the deep waters between the Ionian and the Levantine sub-basin. The same evolution is observed in the Gulf of Lions (in the western basin), with tritium levels being relatively uniform in the deep water. The evolution of the spatial distribution of helium-3 is complementary and related to the penetration of tritium (Fig. 4c and d). The lower concentrations (between 1.5 and 5\%) marked in the Aegean sub-basin, are mostly due to vertical ocean mixing in this region, and an input of surface water depleted in helium-3. The outflow of water through the Straits of the Cretan Arc related with the EMT is characterized with a deep penetration of water enriched with tritium, and depleted in helium-3 (Fig. 4d), which has been uniquely strengthened during the EMT event occurring in the early 1990s (EMT, Roether et al., 1996, 2007).

The tracer ages calculated in March 1995 confirmed the origin of the formation of the deep water and provided an additional estimate for the duration of the mechanism of ventilation. The model produces significant ventilation around the Cretan Arc, illustrated by the very young ages (under 5 years) that are a result of the abrupt change in the EMed during the EMT. That event generates massive penetration of dense water rich in tritium and depleted in helium-3 in the deep Aegean sub-basin. The EMT also causes a remarkable rejuvenation over the Levantine sub-basin with ${ }^{3} \mathrm{H}-{ }^{3} \mathrm{He}$ age under 10 years. Outside of this region, water is becoming older, with a maximum of 25 years at Gibraltar.

Parallel to Figs. 3 and 4, Fig. 5 presents the results in 2005. The tracer distribution in the eastern basin has again become more similar to the classical helium-3 distribution observed in 1987. The tritium distribution between the intermediate and deep waters is similar but is more uniform in the deep water. The maximum tritium concentration in the deep water near the Cretan Arc (Fig. 5b) has disappeared when compared to the situation in 1995. The helium-3 distribution also varies rather little across the deep water in the EMed (5d). 
The main difference simulated in 1995 is a reversal of the areas of intense deep convection between the eastern and western basin. The reduction of the vertical mixing around the Cretan Arc after the EMT generates an increase of helium-3 concentration in the deep water in this region (9\% in 2005 compared to $5 \%$ in 1995). On the other hand, a significant amplification of mixing in the WMed especially in the Gulf of Lions (displayed in Fig. 5d) is characterized by the presence of water very depleted in helium-3 (about $7 \%$ ) in the deep waters.

The ${ }^{3} \mathrm{H}-{ }^{3} \mathrm{He}$ age distribution in 2005 (Fig. 5e and f) confirms the deep convection event being unusually intense in the Gulf of Lions during winter 2004-2005 (Beuvier et al., 2012a). This event is clearly visualized south of France, with the spread of relatively young, deep water masses (15 years compared to the surrounding water that exceeds 25 years). In the eastern basin, and unlike in 1995, the tracer age is higher south of the Cretan Arc (almost double compared to 1995), and the minimum age for the intermediate waters is more pronounced in the Adriatic sub-basin returning towards the pre-EMT situation.

The tracer distribution in 2011 (Fig. 6) is similar to 1987 when no anomalous rate of deep-water formation occurs. The age is increasing in the deep waters of the two basins. After the EMT event, the Aegean Deep Water (AeDW) is less dense, and cannot penetrate at great depths, leaving space for the older Adriatic Deep Water (AdDW). Similarly, in the western basin after the WMT event, the waters become increasingly older, with ages reaching 35 years in the Algerian sub-basin.

\subsection{Model evaluation against observation data}

In the following we evaluate and analyze the simulated temporal evolution of tritium and helium-3 in the Mediterranean Sea against in situ observations from the R/V Meteor (cruises M5/6-1987; M31/1-1995; M44/4-1999; M51/22001; M84/3-2011), and Poseidon 234-1997, along the actual cruise sections in the E-W main axis of the Mediterranean Sea (Fig. 1).

The left column of Fig. 7 (panels a, b, c, d and e) represents the evolution of the tritium distribution in the eastern basin between 1987 and 2011. In 1987 (Fig. 7a), observations are characterized by relatively high tritium concentration $(>3.6 \mathrm{TU})$ in the upper water masses $(<500 \mathrm{~m}$ depth) for all the section except the Levantine sub-basin before passing Crete at $28^{\circ} \mathrm{E}$, where the maximum has a lower value in this LIW source area. The tritium concentration decreases rapidly with depth, marking a significant vertical gradient. The model correctly simulates the tritium concentration in the first $500 \mathrm{~m}$ of the water column, with maximum values of tritium (more than 4.4 TU) in agreement with observations. Deeper the analyses reveal a more pronounced disagreement between model and observation. In the eastern part of the section the model overestimates the penetration of tritium into the intermediate waters. It also tends to underestimate the tritium penetration in the deep Ionian sub-basin, where it fails to produce the maximum concentration associated with EMDW formation (Fig. 7a).

In 1995 (Fig. 7b) we observed a reduction of tritium concentration in the surface layer as a result of mixing with the deeper water masses more depleted in tritium, and the ventilation of LIW, and also as a result of radioactive tritium decay. In 1995 we observed an important penetration of tritium into the deep waters near the Cretan Arc as a consequence of the EMT that enriched bottom tritium concentration giving it a value close to the surface value. The model satisfyingly simulates the evolution of the tritium distribution between the dilution in the surface layer, and the downward penetration of these tritium rich waters to great depths (about $2400 \mathrm{~m}$ depth) between 22 and $26^{\circ} \mathrm{E}$ (Fig. 7b). The simulated values are roughly in agreement with the observation for the first $500 \mathrm{~m}$ (Fig. 8a). However, there is still a disagreement between model and observations in the western part of this section, where simulated tritium values are between 30 and $50 \%$ lower than observation (Fig. 8), since the AdDW signal was not sufficiently ventilated before EMT (see Figs. 7a and $8 \mathrm{a}$ ). The penetration of tritium at the bottom is progressing throughout the basin between 1995 and 2001, especially with the propagation of the signal of recent ventilation from the Cretan Arc (Fig. 7c). The dilution of the tritium concentration in the sub-surface water is still correctly simulated between 1999 and 2001. However, at the bottom the model still underestimates the tritium concentration at the two borders east and west of these sections, as for the previous years. In 2011 the tritium concentration is reduced throughout the basin due to mixing and radioactive decay.

The same sections presented for tritium were also performed for helium-3, which enables one to investigate the LIW ventilation in more detail. Along the transect performed in 1987 (Fig. 7f), surface values are close to the solubility equilibrium of ${ }^{3} \mathrm{He}$, and the maximum of ${ }^{3} \mathrm{He}$ clearly marked the LIW layer between 330 and $600 \mathrm{~m}$ depth. The lowest values are observed near the LIW source areas, and the highest towards the two ends of this section with a maximum value near the Strait of Sicily (about $11 \%$, see Fig. 7f) associated with the higher tritium concentrations observed there. Further down there is a strong decrease of ${ }^{3} \mathrm{He}$ concentration for the entire section, with a maximum concentration associated with EMDW in the Ionian Basin. The model currently reproduces the maximum of helium-3 concentration in the intermediate waters, with values similar to observations, except in the eastern part of the section where it tends to be overestimated. Deeper, we again clearly note the shortfall associated with the too weak EMDW formation in the Adriatic sub-basin, with too low simulated helium-3 values.

In 1995, the helium-3 maximum is still clearly seen in the LIW layer (Fig. 8b), but a significant reduction is observed near the Cretan Arc with a value between 4 and $5 \%$. An important penetration of ${ }^{3} \mathrm{He}$ is observed in deep water at $26^{\circ} \mathrm{E}$ 

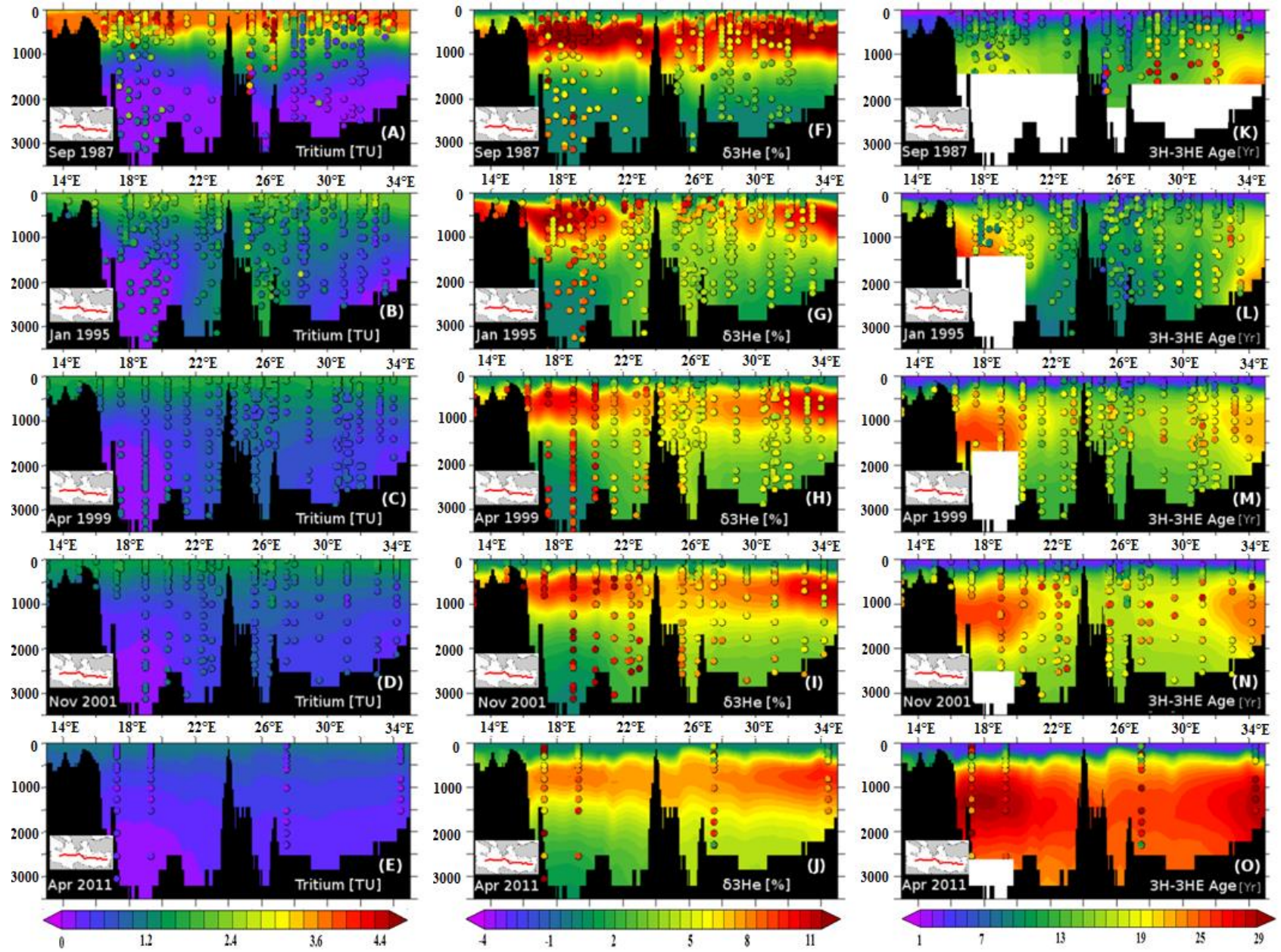

Figure 7. Colour filled contours represents simulated tracer concentration in the EMed, in September 1987, January 1995, April 1999, November 2001 and April 2011. The left column shows tritium concentration in TU, helium-3 in the middle (in \%), and tracer ages (in years) are shown in the right column, whereas colour-filled dots represents in situ observations (Roether et al., 2013). Both use the same colour scale and are taken at the same period. In our simulation we do not calculate the age tracers for the tritium concentration below detection limit (i.e. tritium concentration $<0.1 \mathrm{TU}$ ).

(Fig. 7g) following the amplification of the ocean mixing by the EMT. The model correctly simulates this evolution of the helium-3 distribution during this event, representing realistic helium-3 values for the surface and intermediates waters; however, it tends to underestimate the helium-3 levels in the deep water by $40 \%$ compared to observations (Fig. 8b). In 1999 the concentration in the LIW layer is more uniform in both the model and in situ observations; the deep maximum associated with EMT ventilation is less pronounced compared to the 1995 situation. Comparison with the observed helium-3 suggests a good agreement between simulated helium-3 and data for the LIW layer within the first $500 \mathrm{~m}$ (see Fig. 9b), but as already analyzed for tritium, the model underestimates the helium-3 signal associated with AdDW formation in the deep water.

The right column of Fig. 7 presents the tracer-age estimation, along the sections in the eastern basin. In 1987, the first
$500 \mathrm{~m}$ of the surface layer had a low age, characterized by a high tritium concentration across all the EMed except near the LIW formation area (between 28 and $30^{\circ} \mathrm{E}$ ) where the mixing with older deep waters depleted in tritium increases the tracer age in this region. Deeper the ${ }^{3} \mathrm{H}-{ }^{3} \mathrm{He}$ age increases gradually with a maximum at the two borders of the section in the Levantine and Ionian sub-basins (near the Strait of Sicily).

In 1995, the minimum age layer is shallower, and the values are lower in the centre of the section between 26 and 28 ${ }^{\circ} \mathrm{E}$, with the outflow of waters from the Cretan Arc, which brings young waters (10 years) up to $2400 \mathrm{~m}$ depth in the Levantine sub-basin. Old waters are observed at the bottom in the eastern part of the section $\left(32^{\circ} \mathrm{E}\right)$; the maximum age before the Strait of Sicily is even more pronounced compared to 1987 . The waters become generally older all over the section in 1999. The youngest waters are still located in the cen- 

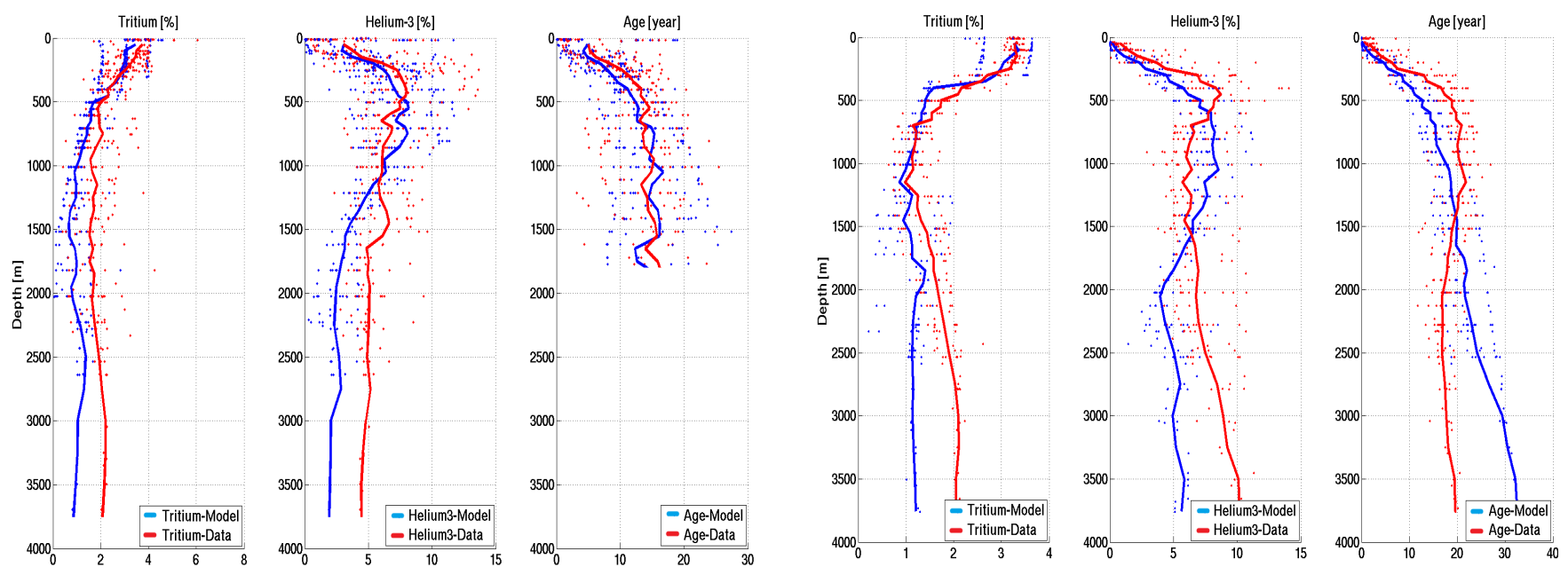

Figure 8. Comparison of average vertical profiles along the METEOR M31/1-1995 section for (left) tritium (TU), (middle) helium$3(\%)$ and (right) the tracer age (in years). Model results are in blue, while red indicates the in situ data. In our simulation we do not calculate the age tracers for the tritium concentration below detection limit (i.e. tritium concentration $<0.1 \mathrm{TU}$ ).

tre of the EMed and the maximum age at the western end. In addition to that we have a significant evolution of the tracerage distribution in the deep waters in the eastern Levantine Basin. Younger water propagation at the bottom generates a transfer of the oldest water between 1000 and $1500 \mathrm{~m}$ depth $\left(26-34^{\circ} \mathrm{E}\right)$. In 2001 the water column structure is very similar to the situation in 1999 with a progressive propagation of old water from the two borders of the EMed. In 2011, the age of the water masses has increased in the whole eastern basin, but still with pronounced maxima at depths between 1000 and $2000 \mathrm{~m}$ near the two ends of the section.

The model correctly simulates the observed evolution of the tracer-age distribution, with values comparable to the estimation from observations (Fig. 8c). It does particularly well at reproducing the evolution associated with the amplification of deep-water formation around the Cretan Arc during the EMT. The propagation of younger water into the bottom of the Levantine sub-basin creates a maximum age at between 1000 and $2000 \mathrm{~m}$ depth, simulated at a realistic timescale by the model. The deep-water accumulation before the Strait of Sicily is also successfully simulated with a tracer age close to that estimated from observation. However, the analysis in the deep water (Figs. 8c and 9c) reveals a more pronounced divergence between the model and the in situ observations. The model generates tracer ages more than 10 years old in 1999 because the model tends to underestimate the tracer penetration in the deep water, due to a lower ventilation of the deep ocean in the simulation.

The results in the WMed (the Alboran, Algerian and Tyrrhenian sub-basins), together with observations made during the Poseidon 234 and Meteor 84/3 cruises in 1997

Figure 9. Comparison of average vertical profiles along the METEOR M44/4-1999 section for (left) tritium (TU), (middle) helium$3(\%)$ and (right) the tracer age (in years). Model results are in blue, while red indicates the in situ data.

and 2011, respectively (presented by circles in our sections) are shown in Fig. 10. The observations on the section made from R/V Poseidon (1997) show a steady decline of ${ }^{3} \mathrm{H}$ concentration from $2 \mathrm{TU}$ at the surface to a minimum of $0.6 \mathrm{TU}$ near $2000 \mathrm{~m}$ depth. In particular, lower tritium concentration is observed in the Tyrrhenian sub-basin, a basin with no deep-water formation and where WMDW mixes with the intermediate water outflows (mainly the LIW and CIW) from the Strait of Sicily. In 2011 (Fig. 10b) the tritium gradient was basically the same as in 1997, but with a lower value in the intermediate water, with concentration decreasing from $0.85 \mathrm{TU}$ at the surface to $0.2 \mathrm{TU}$ at $2000 \mathrm{~m}$ depth. In the bottom of the Algerian sub-basin a relatively higher value of tritium concentration is observed, compared to the Alboran sub-basin.

In 1997 the maximum value of helium-3 is centred near $500 \mathrm{~m}$ depth, a layer occupied by the LIW (Fig. 10c). Above the LIW, the values decrease gradually into the surface layer, which has a helium-3 concentration in equilibrium with the atmosphere. Below the LIW, the decrease of helium- 3 is more moderate, leading to $9.5 \%$ near to $2000 \mathrm{~m}$. In 2011 the helium-3 maximum is shallower (appears between 700 and $1500 \mathrm{~m}$ ) with a higher concentration over the entire water column. The lower values of helium- 3 in the bottom of the Algerian sub-basin (10\% compared to $12 \%$ in the surrounding waters) are related to the WMDW ventilation signal. The ${ }^{3} \mathrm{H}-{ }^{3} \mathrm{He}$ age distributions highlight differences in deep water mass ventilation along these sections (Fig. 10). In 1997 the intermediate waters have basically the same tracer age, but in the deep waters the young ages are noticeable in the Algerian sub-basin at $6^{\circ} \mathrm{E}$, with the maximum in the Tyrrhenian subbasin. In 2011 the age distribution presents similar gradients, but with older ages throughout the entire water column. 

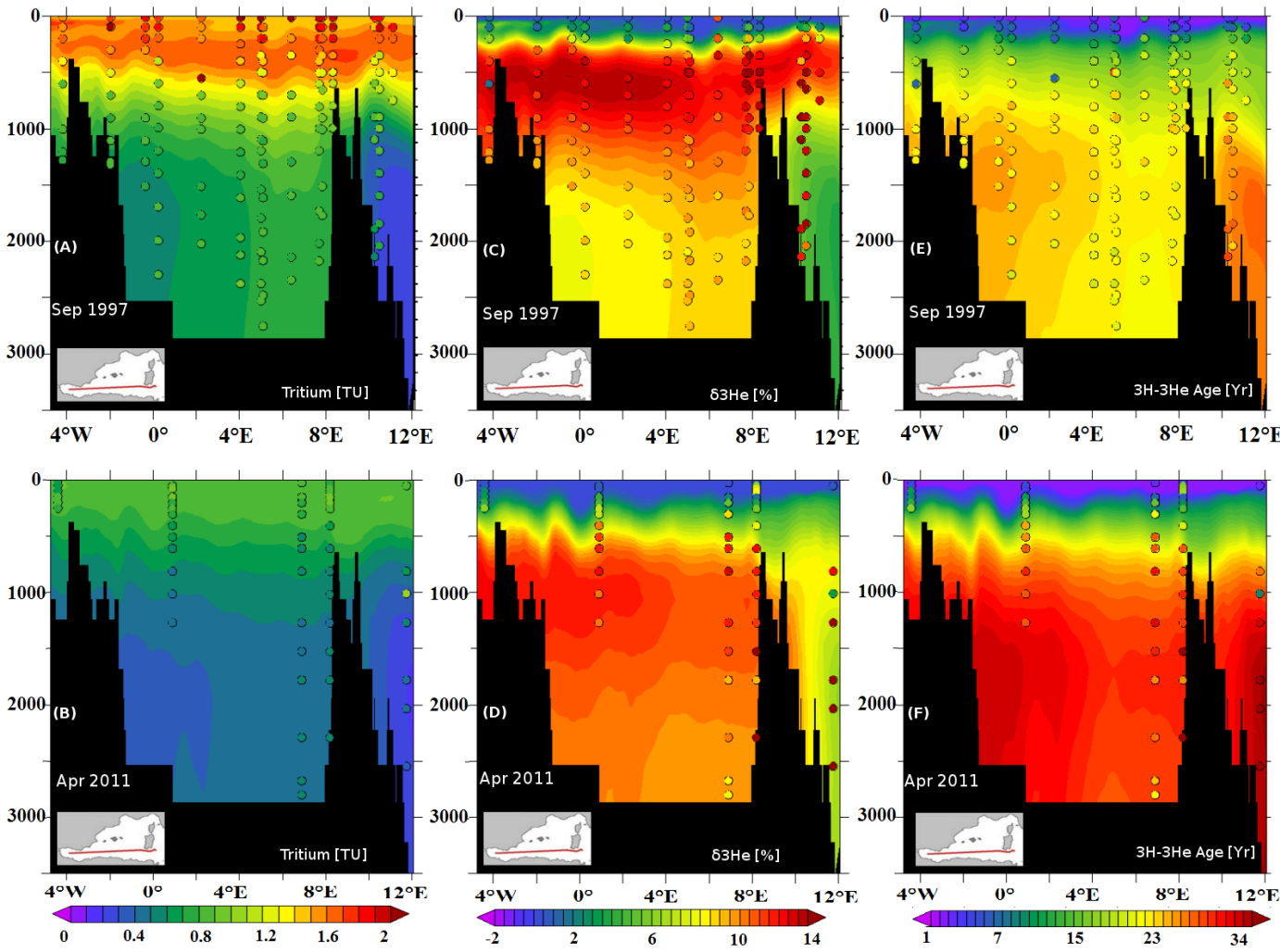

Figure 10. Colour filled contours represents simulated tracer concentration in the WMed, in September 1997 and April 2011. The left column shows tritium concentration in TU, helium-3 in the middle (in \%), and the tracer age (in years) are shown in the right column, whereas colour-filled dots represents in situ observations (Roether et al., 2013). Both use the same colour scale and are taken at the same period. In our simulation we do not calculate the age tracers for the tritium concentration below detection limit (i.e. tritium concentration $<0.1 \mathrm{TU})$.

After the particularly intense deep convection event during the winter of 2005 , the largest volume of dense water was formed in the WMed compared to the 1997 situation. The spreading of WMDW formed in winter 2005 southwards into the Algerian sub-basin was detected with a noticeable signature in helium-3 concentration, where a minimum is observed at the bottom of the southern part of the Algero-Provencal sub-basin. The model correctly simulates the main features of the tracer distributions and their evolution with time between the two cruises (Fig. 10). The pronounced LIW signal in helium-3 in 1997 is particularly well simulated as well as its penetration in depth with time. The contrast in deep water mass ventilation between these two sub-basins is well simulated. The model produces older bottom water masses in Tyrrhenian sub-basin, and the signal related to the propagation of deep water masses formed in the Gulf of Lions is simulated. However, the penetration of new WMDW is weaker in the simulation compared to what was deduced from in situ observations. We simulate the presence of a low helium-3 concentration at the bottom of the AlgeroProvencal sub-basin, but this signal is still lower than in situ observations.

\section{Discussion}

The ${ }^{3} \mathrm{H}-{ }^{3} \mathrm{He}$ simulation provides an independent and additional constraint for modelled water masses ventilation. The evolution of mixing in convection areas and spreading of recently ventilated water at intermediate/deep levels was evaluated by comparison with the observations. Several available observations along large-scale sections allowed a useful evaluation of model performance in the Mediterranean Sea on a long timescale. The tritium input function based on data from the historical tritium time series was tested for the first time in this work. Severe mismatches between model and observations are clearly associated with shortcomings in model physics, otherwise this parameterization led to realistic values of the tracer distribution in the water column. These results suggest that this approach is appropriate for generating a tritium simulation sufficiently valid to evaluate model performance on decadal timescales in the Mediterranean Sea.

The variations of the thermohaline circulation on decadal timescales are well documented by the available ${ }^{3} \mathrm{H}_{-}{ }^{3} \mathrm{He}$ observations. The simulation of these tracers has shown that the main feature of the ventilation and variability of the thermohaline circulation is well captured by the NEMO-MED12 
model. First, the realistic dilution and penetration of the tritium signal from the surface waters indicates that the model generates a realistic mixing with sub-surface water masses over the whole basin. This result indicates that the vertical mixing parameterization used in our model, the TKE closure at an order of 1.5 , is capable of generating a satisfying connection between the surface and sub-surface waters.

Before the EMT (represented here by the 1987 situation), the distribution of the tracer is well structured (Fig. 7a) and reflects a classical distribution of the water masses. The LIW layer is especially characterized by a maximum of helium-3 concentration between 300 and $700 \mathrm{~m}$, and with lower values closest to the LIW formation area east of Rhodes Island. The model simulates correctly the main features of the formation and ventilation of the LIW, producing a vertical distribution of the tracer in agreement with the observations in the intermediate waters. The model particularly demonstrates realistic performance in the Ionian sub-basin upstream of the Strait of Sicily. It produces a strong accumulation of the tracers in the intermediate waters (Fig. 7a and f), which is observed and associated with the presence of the CIW, which joins the LIW (Schlitzer et al., 1991; Roether et al., 1999). Evidence for its presence is provided by the enhanced concentrations of the tracer in the intermediate waters of this area. However, in the eastern part of the Levantine sub-basin, the model tends to overestimate the ventilation of LIW and to generate too high a helium-3 concentration compared to observations. Generation of tritiugenic ${ }^{3} \mathrm{He}$ has now become small relative to the situation in the previous decades (Fig. 2). Therefore, the signature of tracers in the LIW layer has decreased significantly between 1987 and 2011. This evolution in the tracer distribution is also noticeable in our simulations. Indeed the tritium distribution in 2011 was far smoother compared to previous years; on the other hand, helium-3 in this year presents a similar distribution compared to those found earlier, but with a gradual decline. This depletion of helium-3 is evidence of a displacement by upwelling that feeds into the westward return flow, to be eventually transferred into the WMed. The model correctly simulates the aging of the water masses observed in 2011.

The LIW represents the principal movement of water mass from the EMed into the WMed. The tracer age (calculated from the modelled tracer distribution) of the LIW, during the spreading from the Levantine sub-basin (LIW source zone) to the Strait of Sicily, is estimated in our simulation at between 9 and 12 years, and more than $22 \pm 4$ years in the WMed before Gibraltar (Fig. 3). These transit times are in good agreement with the estimates of Roether et al. (2013), which calculate a transit time of $12 \pm 2$ years at the entrance into the Strait of Sicily and $22 \pm 4$ years in the WMed, directly estimated from the repeated observation during different Meteor cruises. Our estimation is also comparable with values obtained by (Gačić et al., 2013) based on salinity anomalies. Exchange processes between EMed and WMed is a fundamental mechanism for the thermohaline circula- tion in the Mediterranean Sea. This result demonstrates that the model simulates this mechanism with the same timescale as in situ observations. Moreover, the model then simulates a satisfying propagation of the LIW into the western basin, demonstrated by the realistic lateral propagation of the associated helium-3 maximum signal at intermediate depth and its downward penetration with time between 1997 and 2011 (Fig. 10).

The tracer simulation has also enabled us to evaluate the formation of deep water and its associated temporal and spatial variability, and to study its impact on the deep water mass renewal over the basin. In the eastern basin, before the EMT (1987; Fig. 7), the signal of deep-water ventilation from the Adriatic sub-basin is too shallow in the simulation compared to observations. This shortcoming was also found in a CFC simulation with the same model NEMO-MED12 (Palmiéri et al., 2015). In the Adriatic sub-basin, the contribution of rivers is very important; however, the atmospheric forcing ARPERA combined with the river runoff data set overestimate the freshwater flux, and provide too much freshwater on this domain. This results in unusually low-salinity water compared to observations, and further prevents winter convection, and therefore the AdDW formed is too light and not dense enough to propagate to the bottom of the Ionian subbasin.

The sequence of the EMT events occurring in the eastern basin at the beginning of the 1990s has completely changed the deep water mass structure. The evolution of the tritium distribution between 1995 and 2001 demonstrates that the water mass structure was very different from the pre-EMT picture (see Fig. 7). These sections demonstrate a considerable dilution of tracer concentrations in the surface water, following a significant amplification of mixing in the EMed, when surface water rich in tritium are transferred to the bottom. The model has successfully simulated this amplification of mixing caused by the EMT and generated an appropriate EMDW ventilation with realistic values of tritium concentration at the bottom. The section in 1995 emphasizes the severe impact of the EMT on water mass distribution, which transfers massive volumes of tritium-rich near-surface waters into the deep layers, with the highest contributions toward the bottom and south of Crete (Fig. 7b), causing a temporary change in the EMDW origin, from the Adriatic to Aegean sub-basin in 1992-1993. Different hypotheses concerning the preconditioning of the EMT and its timing have been proposed in the literature (see Sect. 1). The in situ observations were essential to discover the EMT, but they cannot give a clear description of the ocean evolution between the past and the actual situation, which does not give us a clear choice between the various proposed hypotheses leading to the EMT. On the other hand, numerical modelling gives us a clear 4-D description, which provides an additional opportunity to test these different hypotheses proposed by in situ data at larger spatial and temporal scales. The new configuration of NEMOMED12 at $1 / 12^{\circ}$ degree resolution, allows for a better simu- 
lation of the EMT (Beuvier, 2011). The outflow of this new very dense water, rich in tritium and depleted in helium-3, from the Cretan Arc straits is clearly observed and correctly simulated in 1995 (Fig. 4) compared to the situation in the other years (Figs. 3, 5 and 6), which gives clear evidence that during the EMT, the EMDW was not formed in the Adriatic sub-basin but in the Aegean sub-basin. The ${ }^{3} \mathrm{H}-{ }^{3} \mathrm{He}$ age confirms this conclusion considering the pronounced overflow of recently ventilated waters from the Cretan Arc straits in 1995 (Fig. 4e and f) vs. the other years when the EMDW was formed mainly in the Adriatic sub-basin. Among the preconditioning and triggering elements of the EMT suggested in the literature, (Beuvier et al., 2010) suggested that the main factors are the intense winter fluxes over the Aegean subbasin during winters 1992 and 1993.

The transient evolution of the tracer age, between 1987 and 2001, in the eastern basin clearly shows a renewal of the deep water masses and provides an additional diagnostic to assess the timescales of this mechanism. The increased deep convection caused by the EMT, enhanced the propagation of the relatively young waters (recently ventilated) at the bottom of the Levantine sub-basin, which displaced the preceding bottom waters (Fig. 7k) up to $1000 \mathrm{~m}$ depth in 2001 (Fig. 7n). The model succeeds in simulating this observed renewal of the bottom waters, and reorganization of the deep waters in the eastern basin; the tracer age shows that this mechanism is simulated with a realistic timescale. The ${ }^{3} \mathrm{H}-$ ${ }^{3} \mathrm{He}$ age can hardly be older than the time between the tritium peak and the time of observation. For example the deep waters of the Levantine Sea have a ${ }^{3} \mathrm{H}-{ }^{3} \mathrm{He}$ age of no more than about 30 years, while a box-model evaluation (Roether and Schlitzer, 1991) estimates a renewal rate of the order of 150 years. The reason is the most pronounced tritium peak in the 1960s, which has the consequence that the pre-peak years have little influence on the tracer-age estimation. Only when the bulk of the water leaves the surface at a time when the tritium concentration has decreased sufficiently, does this effect become small. In the LIW layer the effect is small because the water is younger and the LIW is largely an advective system, whereas in the deep-waters mixing predominates.

The gradual decline of tritium concentrations in the EMed after 1987 is mainly not only due to a westward drift of intermediate waters, which renews the waters in the eastern basin but also due to the cessation of atmospheric nuclear weapons testing, which reduced the transfer of anthropogenic tritium in the mixed layer to as little as about twice the natural background level (Roether et al., 2013).

In the western basin the thermohaline circulation cell is driven by deep-water formation in the Gulf of Lions, and it spreads from there, with intense mesoscale phenomena along the coastal current. The system of deep convection in the Gulf of Lions had a particularly intense event observed during winter of 2005 (López-Jurado et al., 2005; Canals et al., 2006; Schroeder et al., 2008) and to a lesser extent during the following years, when the convection occurred over a much larger and deeper area than usual. This intense formation of dense water in the Gulf of Lions has already been simulated by (Beuvier et al., 2012a) et al. (2012a) with the model used in this study. This transition is well represented in our tracer simulation for March 2005 (Fig. 5d), with a pronounced invasion of the helium-3 in the Liguro-Provencal sub-basin.

In the Algerian sub-basin (Fig. 10a), relatively higher tritium concentrations are found and lower values of helium-3 compared to those marked in the Alboran sub-basin, indicating the impact of the newly formed WMDW. However, the southern propagation of this recently ventilated water in the deep sea is too slow, as the deep flow is strongly constrained by the interaction between the bathymetry and the eddy activity. In addition, the new WMDW formed in the model is not salty enough with respect to these observations (Beuvier et al., 2012a) with the model used in this study. Its southwards propagation is also too slow compared to in situ and satellite observation (Beuvier, et al., 2012a) of the model used in this study. The same vertical gradient of tritium observed in 1997 is marked in 2011 in the WMed, with lower concentrations in the water column following the drastic reduction of tritium in the atmosphere after the stopping of the atmospheric nuclear weapons testing. Helium-3 maximum in LIW is deeper (about $1000 \mathrm{~m}$ ) in 2011 , with a significant accumulation of helium-3 in the deep water compared to 1997 , which is due to continued tritium decay on the way. This evolution of the tracer signals was successfully simulated by the model indicating that the conversion of LIW in the western basin is well simulated.

\section{Conclusions}

The anthropogenic tritium invasion and its decay product helium-3 was simulated for the first time in the Mediterranean Sea, using a high-resolution regional model (NEMOMED12) at $1 / 12^{\circ}$ of horizontal resolution $(6-8 \mathrm{~km})$. The formulation used for the tritium boundary conditions led to results of sufficient quality to allow them to be used for evaluating the circulation of the model. ${ }^{3} \mathrm{H}-{ }^{3} \mathrm{He}$ observations available along a number of cruises have enabled us to evaluate the decadal variability of the thermohaline circulation in the Mediterranean Sea. The model correctly simulates the main features of the thermohaline circulation of the Mediterranean Sea, with mechanisms having a realistic timescale compared to estimations from observations. The Eastern Mediterranean Transient (EMT) signal from the Aegean sub-basin was simulated, with its corresponding penetration of tracers into the deep water in early 1995. The strong convection event of winter 2005 and the following years in the Gulf of Lions was also simulated. The tracer-age diagnostic provided an interesting tool to assess the ventilation and propagation of intermediate and deep water. We show that some main features of decadal evolution of water masses are well simulated by the model. Especially the transient evolution of the tracer age 
in the eastern basin revealed that the renewal of the bottom water masses is correctly simulated after the EMT. The connection between the eastern basin towards the western basin, undertaken by the spreading of the Levantine Intermediate Water (LIW) is realistically simulated with transit times (between 17 and 26 years), comparable with other estimates.

However, some aspects in the simulation still need to be improved. In the eastern basin, the tracer simulation results highlight the too weak formation of Adriatic Deep Water (AdDW), followed by a weak contribution to the EMDW in the Ionian sub-basin. The production of WMDW is correct but the spreading of the recently ventilated deep water to the South of the western basin is too weak. Also the LIW is well represented by the helium-3 signal, but shows too high values in the eastern end of EMed, due to overestimation of the formation of LIW in this region.
Our work proposes additional constraints on the subsurface circulation and ocean mixing processes in the Mediterranean Sea. These new tracer simulations and their comparison with recent in situ observations and with other tracer elements (e.g. CFC or carbon-14) provide a new and additional expertise to assess and improve the dynamical regional model NEMO-MED12. This evaluation was fundamental before using NEMO-MED12 as dynamical components in coupled models for studying the evolution of the climate and its effect on the biogeochemical cycles in the Mediterranean Sea, and is essential to improve our ability to predict the future evolution of the Mediterranean Sea under the increasing anthropogenic pressure. 


\section{Appendix A}

Table A1. List of acronyms used in the paper.

\begin{tabular}{ll}
\hline Acronyms & Meaning \\
\hline AW & Atlantic Water (Surface water of Atlantic origin) \\
LIW & Levantine Intermediate Water \\
WMDW & Western Mediterranean Deep Water \\
TDW & Tyrrhenian Deep Water. \\
NAdDW & North Adriatic Deep Water (Formerly NADW) \\
or NADDW & \\
AdDW & Adriatic Deep Water (Formed in the southern Adriatic, \\
& main component of the EMDW and sometimes called SADW) \\
CDW & Cretan Deep Water \\
LDW & Levantine Deep Water (Formed in NW Levantine Basin) \\
EMDW & Eastern Mediterranean Deep Water (Kept for historical reasons) \\
EOW & Eastern Mediterranean Overflow Water (Sometimes called AIW \\
& or tEMDW at the Strait of Sicily) \\
MOW & Mediterranean Outflow Water (At the Strait of Gibraltar) \\
& (MW in the Atlantic) \\
tEMDW & transitional Eastern Mediterranean Deep Water \\
EMT & Eastern Mediterranean Transient \\
WMT & Western Mediterranean Transition \\
EMed & Eastern Mediterranean Basin \\
WMed & Western Mediterranean Basin \\
NWMed & North Western Mediterranean \\
\hline
\end{tabular}


Acknowledgements. We would like to thank M. Hoppema and anonymous reviewer for their careful reading of the manuscript and helpful remarks.

Edited by: M. Hoppema

\section{References}

Andrie, C. and Merlivat, L.: Tritium in the western Mediterranean Sea during 1981 Phycemed cruise, Deep-Sea Res. Pt. I, 35, $247-$ 267, doi:10.1016/0198-0149(88)90039-8, 1988.

Antonov, J. I., Locarnini, R. A., Boyer, T. P., Mishonov, A. V., and Garcia, H. E.: World Ocean Atlas 2005, Vol. 2 Salinity, edited by: Levitus, S., NOAA Atlas NESDIS 62, US Government Printing Office, Washington, DC, 182 pp., 2006.

Attané, I. and Courbage, Y.: Demography in the Mediterranean region: situation and projections, Plan Bleu, Paris, Economica, available at: http://ersilia.net/ET2050_library/docs/med/demo_ plan_bleu.pdf, 2004.

Barnier, B., Siefridt, L., and Marchesiello, P.: Thermal forcing for a global ocean circulation model using a three-year climatology of ECMWF analyses, J. Marine Syst., 6, 363-380, doi:10.1016/0924-7963(94)00034-9, 1995.

Béranger, K., Mortier, L., Gasparini, G.-P., Gervasio, L., Astraldi, M., and Crépon, M.: The dynamics of the Sicily Strait: a comprehensive study from observations and models, Deep-Sea Res. Pt. II, 51, 411-440, doi:10.1016/j.dsr2.2003.08.004, 2004.

Béranger, K., Mortier, L., and Crépon, M.: Seasonal variability of water transport through the Straits of Gibraltar, Sicily and Corsica, derived from a high-resolution model of the Mediterranean circulation, Prog. Oceanogr., 66, 341-364, doi:10.1016/j.pocean.2004.07.013, 2005.

Beuvier, J.: Modélisation de la variabilité climatique et des masses d'eau en mer Méditerranée: Impact des échanges océanatmosphère, $\mathrm{PhD}$ thesis, Ecole Polytechnique, Palaiseau, France, 2011.

Beuvier, J., Sevault, F., Herrmann, M., Kontoyiannis, H., Ludwig, W., Rixen, M., Stanev, E., Béranger, K., and Somot, S.: Modeling the Mediterranean Sea interannual variability during 1961-2000: Focus on the Eastern Mediterranean Transient, J. Geophys. Res., 115, C08017, doi:10.1029/2009JC005950, 2010.

Beuvier, J., Béranger, K., Lebeaupin Brossier, C., Somot, S., Sevault, F., Drillet, Y., Bourdallé-Badie, R., Ferry, N., and Lyard, F.: Spreading of the Western Mediterranean Deep Water after winter 2005: Time scales and deep cyclone transport, J. Geophys. Res., 117, C07022, doi:10.1029/2011JC007679, 2012a.

euvier, J., Lebeaupin Brossier, C., Béranger, K., Arsouze, T., Bourdallé-Badie, R., Deltel, C., Drillet, Y., Drobinski, P., Lyard, F., Ferry, N., Sevault, F., and Somot, S.: MED12, Oceanic component for the modelling of the regional Mediterranean Earth System, Mercator Ocean Quarterly Newsletter, 46, 60-66, 2012b.

Blanne, B. and Delecluse, P.: Low frequency variability of the tropical Atlantic Ocean simulated by a general circulation model with mixed layer physics, J. Phys. Oceanogr, 23, 1363-1388, 1993.

Broecker, W. and Peng, T.-H.: Tracers in the Sea: Palisades, NY (Lamont-Doherty Geol. Observ.), 1982.
Canals, M., Puig, P., de Madron, X. D., Heussner, S., Palanques, A., and Fabres, J.: Flushing submarine canyons., Nature, 444, 354357, doi:10.1038/nature05271, 2006.

CIESM: Workshop CIESM Monograph no. 38 on Dynamics of Mediterranean deep waters, edited by: Briand, F., Monaco, 2001.

Clarke, W., Jenkins, W., and Top, Z.: Determination of tritium by mass spectrometric measurement of ${ }^{3} \mathrm{He}$, The International Journal of Applied Radiation and Isotopes, 27, 515-522, doi:10.1016/0020-708X(76)90082-X, 1976.

CLIPPER Project Team: Modélisation à haute résolution de la circulation dans l'océan Atlantique forcée et couplée océanatmosphére, Sci. Tech. Rep. CLIPPER-R3-99, Ifremer, Brest, France, 1999.

Delhez, E., Deleersnijder, E., Mouchet, A., and Beckers, J.-M.: A note on the age of radioactive tracers, J. Marine Syst., available at: http://www.jpi-oceans.eu/imis?module=ref\&refid= 62419, 2003.

Diffenbaugh, N. S. and Giorgi, F.: Climate change hotspots in the CMIP5 global climate model ensemble, Climatic change, 114, 813-822, doi:10.1007/s10584-012-0570-x, 2012.

Doney, S. C., Glover, D. M., and Jenkins, W. J.: A model function of the global bomb tritium distribution in precipitation, 1960-1986, J. Geophys. Res., 97, 5481, doi:10.1029/92JC00015, 1992.

Dreisigacker, E. and Roether, W.: Tritium and 90-strontium in North Atlantic surface water, Earth Planet. Sci. Lett, 38, 301-312, 1978.

Drobinski, P., Anav, A., Lebeaupin Brossier, C., Samson, G., Stéfanon, M., Bastin, S., Baklouti, M., Béranger, K., Beuvier, J., Bourdallé-Badie, R., Coquart, L., D’Andrea, F., de NobletDucoudré, N., Diaz, F., Dutay, J.-C., Ethe, C., Foujols, M.-A., Khvorostyanov, D., Madec, G., Mancip, M., Masson, S., Menut, L., Palmieri, J., Polcher, J., Turquety, S., Valcke, S., and Viovy, N.: Model of the Regional Coupled Earth system (MORCE): Application to process and climate studies in vulnerable regions, 35, 1-18, doi:10.1016/j.envsoft.2012.01.017, 2012.

Farley, K. A., Maier-Reimer, E., Schlosser, P., and Broecker, W. S.: Constraints on mantle 3 He fluxes and deep-sea circulation from an oceanic general circulation model, J. Geophys. Res., 100, 3829, doi:10.1029/94JB02913, 1995.

Ferry, N., Parent, L., Garric, G., Barnier, B., and Jourdain, N. C.: Mercator Global Eddy Permitting Ocean Reanalysis GLORYS1V1: Description and Results, Mercator Ocean Q. Newslett., 36, 15-28, 2010.

Gasparini, G., Ortona, A., Budillon, G., Astraldi, M., and Sansone, E.: The effect of the Eastern Mediterranean Transient on the hydrographic characteristics in the Strait of Sicily and in the Tyrrhenian Sea, Deep-Sea Res. Pt. I, 52, 915-935, doi:10.1016/j.dsr.2005.01.001, 2005.

Gacčić, M., Schroeder, K., Civitarese, G., Cosoli, S., Vetrano, A., and Eusebi Borzelli, G. L.: Salinity in the Sicily Channel corroborates the role of the Adriatic-Ionian Bimodal Oscillating System (BiOS) in shaping the decadal variability of the Mediterranean overturning circulation, Ocean Sci., 9, 83-90, doi:10.5194/os-983-2013, 2013.

Gertman, I., Pinardi, N., Popov, Y., and Hecht, A.: Aegean Sea Water Masses during the Early Stages of the Eastern Mediterranean Climatic Transient (1988-90), J. Phys. Oceanogr., 36, 1841-1859, doi:10.1175/JPO2940.1, 2006. 
Giorgi, F.: Climate change hot-spots, Geophys. Res. Lett., 33, L08707, doi:10.1029/2006GL025734, 2006.

Gualdi, S., Somot, S., Li, L., Artale, V., Adani, M., Bellucci, A., Braun, A., Calmanti, S., Carillo, A., Dell'Aquila, A., Déqué, M., Dubois, C., Elizalde, A., Harzallah, A., Jacob, D., L'Hévéder, B., May, W., Oddo, P., Ruti, P., Sanna, A., Sannino, G., Scoccimarro, E., Sevault, F., and Navarra, A.: The circe simulations: Regional climate change projections with realistic representation of the mediterranean sea, B. Am. Meteorol. Soc., 94, 65-81, doi:10.1175/BAMS-D-11-00136.1, 2013.

Haine, T. W. N. and Hall, T. M.: No TitleA generalized transport theory: water-mass composition and age, J. Phys. Oceanogr., 32, 1932-1946, 2002.

Herrmann, M., Somot, S., Sevault, F., Estournel, C., and Déqué, M.: Modeling the deep convection in the northwestern Mediterranean Sea using an eddy-permitting and an eddy-resolving model: Case study of winter 1986-1987, J. Geophys. Res., 113, C04011, doi:10.1029/2006JC003991, 2008.

Herrmann, M., Sevault, F., Beuvier, J., and Somot, S.: What induced the exceptional 2005 convection event in the northwestern Mediterranean basin? Answers from a modeling study, J. Geophys. Res., 115, C12051, doi:10.1029/2010JC006162, 2010.

Herrmann, M. J. and Somot, S.: Relevance of ERA40 dynamical downscaling for modeling deep convection in the Mediterranean Sea, Geophys. Res. Lett., 35, L04607, doi:10.1029/2007GL032442, 2008.

Jenkins, W. and Clarke, W.: The distribution of $3 \mathrm{He}$ in the western Atlantic ocean, Deep-Sea Research and Oceanographic Abstracts, 23, 481-494, doi:10.1016/0011-7471(76)90860-3, 1976.

Jenkins, W. J.: On the climate of a subtropical ocean gyre: decade timescale variations in water mass renewal in the Sargasso Sea, J. Mar. Res, 40, 265-290, 1982.

Jenkins, W. J.: ${ }^{3} \mathrm{H}$ and ${ }^{3} \mathrm{He}$ in the Beta triangle; observation of gyre ventilation and oxygen utilization rates, J. Phys. Oceanogr, 17, 763-783, 1987.

Jia, Y. and Richards, K. J.: Tritium distributions in an isopycnic model of the North Atlantic, J. Geophys. Res., 101, 11883, doi:10.1029/95JC03674, 1996.

Josey, S. A.: Changes in the heat and freshwater forcing of the eastern Mediterranean and their influence on deep water formation, J. Geophys. Res., 108, 3237, doi:10.1029/2003JC001778, 2003.

Klein, B., Roether, W., Manca, B., Bregant, D., Beitzel, V., Kovacevic, V., and Luchetta, A.: The large deep water transient in the Eastern Mediterranean, Deep-Sea Res., 46, 371-414, 1999.

Lascaratos, A., Roether, W., Nittis, K., and Klein, B.: Recent changes in deep water formation and spreading in the eastern Mediterranean Sea: a review, Prog. Oceanogr., 44, 5-36, doi:10.1016/S0079-6611(99)00019-1, 1999.

Lebeaupin Brossier, C., Béranger, K., Deltel, C., and Drobinski, P.: The Mediterranean response to different spacetime resolution atmospheric forcings using perpetual mode sensitivity simulations, Ocean Model., 36, 1-25, doi:10.1016/j.ocemod.2010.10.008, 2011.

Locarnini, R. A., Mishonov, A. V., Antonov, J. I., Boyer, T. P., and Garcia, H. E.: World Ocean Atlas 2005, Volume 1: Temperature, S. Levitus, Ed, NOAA Atlas NESDIS 61, US Government Printing Office, Washington, DC, 182 pp., 2006.

López-Jurado, J.-L., González-Pola, C., and Vélez-Belchí, P.: Observation of an abrupt disruption of the long-term warming trend at the Balearic Sea, western Mediterranean Sea, in summer 2005 , Geophys. Res. Lett., 32, L24606, doi:10.1029/2005GL024430, 2005.

Lucas, L. L. and Unterweger, M. P.: Comprehensive review and critical evaluation of the half-life of tritium, J. Res. Natl. Inst. Stan., 105, 541-549, doi:10.1021/ja0048230, 2000.

Ludwig, W., Dumont, E., Meybeck, M., and Heussner, S.: River discharges of water and nutrients to the Mediterranean and Black Sea: Major drivers for ecosystem changes during past and future decades?, Prog. Oceanogr., 80, 199-217, doi:10.1016/j.pocean.2009.02.001, 2009.

Madec, G. and NEMO-Team.: Note du Pôle de modélisation, Institut Pierre-Simon Laplace (IPSL), France, NEMO ocean engine, 27, ISSN N1288-1619, 2008.

Malanotte-Rizzoli, P. and Robinson, A. R.: POEM: Physical Oceanography of the Eastern Miditerranean, Eos, Transactions American Geophysical Union, 69, 194, doi:10.1029/88EO00125, 1988.

Malanotte-Rizzoli, P., Manca, B. B., D’Alcala, M. R., Theocharis, A., Brenner, S., Budillon, G., and Ozsoy, E.: The Eastern Mediterranean in the 80s and in the 90s: the big transition in the intermediate and deep circulations, Dynam. Atmos. Oceans, 29, 365-395, doi:10.1016/S0377-0265(99)00011-1, 1999.

Mann, W., Unterweger, M., and Coursey, B.: Comments on the NBS tritiated-water standards and their use, The International Journal of Applied Radiation and Isotopes, 33, 383-386, doi:10.1016/0020-708X(82)90153-3, 1982.

MEDAR-MedAtlas-group: Medar-Medatlas Protocol (Version 3) Part I: Exchange Format and Quality Checks for Observed Profiles, P. Rap. Int. IFREMER/TMSI/IDM/SISO02-006, 50, 2002.

MerMex-Groue: Marine ecosystems' responses to climatic and anthropogenic forcings in the Mediterranean, Prog. Oceanogr., 91, 97-166, doi:10.1016/j.pocean.2011.02.003, 2011.

Miller, A. R.: Physical Oceanography of the Mediterranean Sea: a discourse, 17, 857-871, 1963.

Millot, C.: Levantine Intermediate Water characteristics: an astounding general misunderstanding!, Sci. Mar., 77, 217-232, doi:10.3989/scimar.03518.13A, 2013.

Millot, C. and Taupier-Letage, I.: Circulation in the Mediterranean Sea, The Handbook of Environmental Chemistry, 5, 29-66, doi:10.1007/b107143, 2005.

Nielsen, J.: Hydrography of the Mediterranean and adjacent waters. J. Schmidt, editor, in: Report on the Danish Oceanog-raphic expeditions 1908-1910 to the Mediterranean and adjacent seas, edited by: Host, A. F. and son, Copenhagen, 1, 77-191, 1992.

Östlund, H. G.: Expedition Odysseus.: Tritium and Radiocarbon in the Mediterranean and Black Seas. Report ML 69167, Inst. of Marine and Atmosph. Sciences, Univ. of Miami, 1969.

Palmiéri, J., Orr, J. C., Dutay, J.-C., Béranger, K., Schneider, A., Beuvier, J., and Somot, S.: Simulated anthropogenic CO2 storage and acidification of the Mediterranean Sea, Biogeosciences, 12, 781-802, doi:10.5194/bg-12-781-2015, 2015.

Pinardi, N., Zavatarelli, M., Adani, M., Coppini, G., Fratianni, C., Oddo, P., Simoncelli, S., Tonani, M., Lyubartsev, V., Dobricic, S., and Bonaduce, A.: Mediterranean Sea large-scale low-frequency ocean variability and water mass formation rates from 1987 to 2007: A retrospective analysis, Prog. Oceanogr., 132, 318-332, doi:10.1016/j.pocean.2013.11.003, 2013. 
POEM-group: General circulation of the Eastern Mediterranean, Earth-Sci. Revi., 32, 285-309, doi:10.1016/00128252(92)90002-B, 1992.

Rixen, M., Beckers, J. M., Levitus, S., Antonov, J., Boyer, T., Maillard, C., Fichaut, M., Balopoulos, E., Iona, S., Dooley, H., Garcia, M. J., Manca, B., Giorgetti, A., Manzella, G., Mikhailov, N., Pinardi, N., and Zavatarelli, M.: The Western Mediterranean Deep Water: A proxy for climate change, Geophys. Res. Lett., 32, 1-4, doi:10.1029/2005GL022702, 2005.

Roether, W. and Well, R.: Oxygen consumption in the Eastern Mediterranean, Deep-Sea Res. Pt. I, 48, 1535-1551, doi:10.1016/S0967-0637(00)00102-3, 2001.

oether, W. and Schlitzer, R.: Eastern Mediterranean deep water renewal on the basis of chlorofluoromethane and tritium data, Dyn. Atmos. Oceans, 15, 333-354, 1991.

Roether, W., Manca, B. B., Klein, B., Bregant, D., Georgopoulos, D., Beitzel, V., Kovacevic, V., and Luchetta, A.: Recent Changes in Eastern Mediterranean Deep Waters, Science, 271, 333-335, doi:10.1126/science.271.5247.333, 1996.

Roether, W., Well, R., Putzka, A., and Rüth, C.: Component separation of oceanic helium, J. Geophys. Res., 103, 27931, doi:10.1029/98JC02234, 1998.

Roether, W., Beitzel, V., Sültenfuß, J., and Putzka, A.: The Eastern Mediterranean tritium distribution in 1987, J. Marine Syst., 20, 49-61, doi:10.1016/S0924-7963(98)00070-0, 1999.

Roether, W., Klein, B., Manca, B. B., Theocharis, A., and Kioroglou, S.: Transient Eastern Mediterranean deep waters in response to the massive dense-water output of the Aegean Sea in the 1990s, Prog. Oceanogr., 74, 540-571, doi:10.1016/j.pocean.2007.03.001, 2007.

Roether, W., Jean-Baptiste, P., Fourré, E., and Sültenfuß, J.: The transient distributions of nuclear weapon-generated tritium and its decay product ${ }^{3} \mathrm{He}$ in the Mediterranean Sea, 1952-2011, and their oceanographic potential, Ocean Sci., 9, 837-854, doi:10.5194/os-9-837-2013, 2013.

Samuel, S., Haines, K., Josey, S., and Myers, P. G.: Response of the Mediterranean Sea thermohaline circulation to observed changes in the winter wind stress field in the period 1980-1993, J. Geophys. Res., 104, 7771, doi:10.1029/1998JC900130, 1999.

Sarmiento, J. L.: A Simulation of Bomb Tritium Entry into the Atlantic Ocean. J. Phys. Oceanogr., 13, 1924-1939. doi:10.1175/1520-0485(1983)013<1924:ASOBTE>2.0.CO;2, 1983.

Sarmiento, J. L. and Gruber, N.: Ocean Biogeochemical Dynamics, 2006.

Schlitzer, R., Roether, W., Oster, H., Junghans, H.-G., Hausmann, M., Johannsen, H., and Michelato, A.: Chlorofluoromethane and oxygen in the Eastern Mediterranean, Deep-Sea Res. Pt. A, 38, 1531-1551, doi:10.1016/0198-0149(91)90088-W, 1991.

Schroeder, K., Ribotti, A., Borghini, M., Sorgente, R., Perilli, a., and Gasparini, G. P.: An extensive western Mediterranean deep water renewal between 2004 and 2006, Geophys. Res. Lett., 35, 1-7, doi:10.1029/2008GL035146, 2008.

Schroeder, K., Garcìa-Lafuente, J., Josey, S., Artale, V., Nardelli, B. B., Gacic, M., Gasparini, G., Herrmann, M., Lionello, P., Ludwig, W., Millot, C., Özsoy, E., Pisacane, G., Sánchez-Garrido, J., Sannino, G., Santoleri, R., Somot, S., Struglia, M., Stanev, E., Taupier-Letage, I., Tsimplis, M., Vargas-Yáñez, M., Zervakis, V., and Zodiatis, G.: Circulation of the Mediterranean Sea and its variability, in: The climate of the Mediterranean region, edited by: Lionello, P., Elsevier, 187-256, 2012.

Somot, S., Sevault, F., and Déqué, M.: Transient climate change scenario simulation of the Mediterranean Sea for the twenty-first century using a high-resolution ocean circulation model, Clim. Dynam., 27, 851-879, doi:10.1007/s00382-006-0167-z, 2006.

Soto-Navarro, J., Somot, S., Sevault, F., Beuvier, J., Béranger, K., Criado-Aldeanueva, F., and García-Lafuente, J.: Evaluation of regional ocean circulation models for the Mediterranean Sea at the Strait of Gibraltar: volume transport and thermohaline properties of the outflow, Clim. Dynam., 44, 1277-1292, doi:10.1007/s00382-014-2179-4, 2014.

Stanev, E. V. and Peneva, E. L.: Regional sea level response to global climatic change: Black Sea examples, Europe, 32, 33-47, 2002.

Theocharis, A., and Kontoyiannis, H.: Interannual variability of the circulation and hydrography in the eastern Mediterranean (19861995), in The Eastern Mediterranean as a Laboratory Basin for the Assessment of Contrasting Ecosystems, NATO Sci. Ser.: 2. Environ. Security, Vol. 51, edited by: P. Malanotte-Rizzoli, and V. N. Eremeev, 453-464, Kluwer Acad., Dordrecht, Netherlands, 1999.

Theocharis, A., Georgopoulos, D., Karagevrekis, P., Iona, A., Perivoliotis, L., and Charalambidis, N.: Aegean influence in the deep layers of the Eastern Ionian Sea, Rapport de la Commission international pour l'Exploration Scientifique de la Mer Méditerranée, 33, 235, 1992.

Theocharis, A., Nittis, K., Kontoyiannis, H., Papageorgiou, E., and Balopoulos, E.: Climatic changes in the Aegean Sea influence the Eastern Mediterranean thermohaline circulation (1986-1997), Geophys. Res. Lett., 26, 1617-1620, 1999.

Theocharis, A., Klein, B., Nittis, K., and Roether, W.: Evolution and status of the Eastern Mediterranean Transient (19971999), J. Marine Syst., 33-34, 91-116, doi:10.1016/S09247963(02)00054-4, 2002.

Thiele, G. and Sarmiento, J. L.: Tracer dating and ocean ventilation, J. Geophys. Res., 95, doi:10.1029/JC095iC06p09377, 9377-9391, 1990.

Vörösmarty, C. J., Fekete, B. M., and Tucker, B. A.: Global River Discharge Database (RivDIS V1.0), International Hydrological Program, Global Hydrological Archive and Analysis Systems, UNESCO, Paris, 1996.

Weiss, W. and Roether, W.: The rates of tritium input to the world oceans, Earth and Planet. Sci. Lett., 49, 435-446, doi:10.1016/0012-821X(80)90084-9, 1980.

Weiss, W., Bullacher, J., and Roether, W.: Evidence of pulsed discharges of tritium from nuclear energy installations in central European precipitation, In Behaviour of Tritium in the Environment, 17-30, IAEA-SM-232/18, IAEA, Vienna, 1979.

Zervakis, V., Georgopoulos, D., and Drakopoulos, P. G.: The role of the North Aegean in triggering the recent Eastern Mediterranean climatic changes, J. Geophys. Res., 105, 26103-26116, 2000. 